$\mathbb{1}$ Nordic Council of Ministers

Nordic eHealth benchmarking

From piloting towards established practice

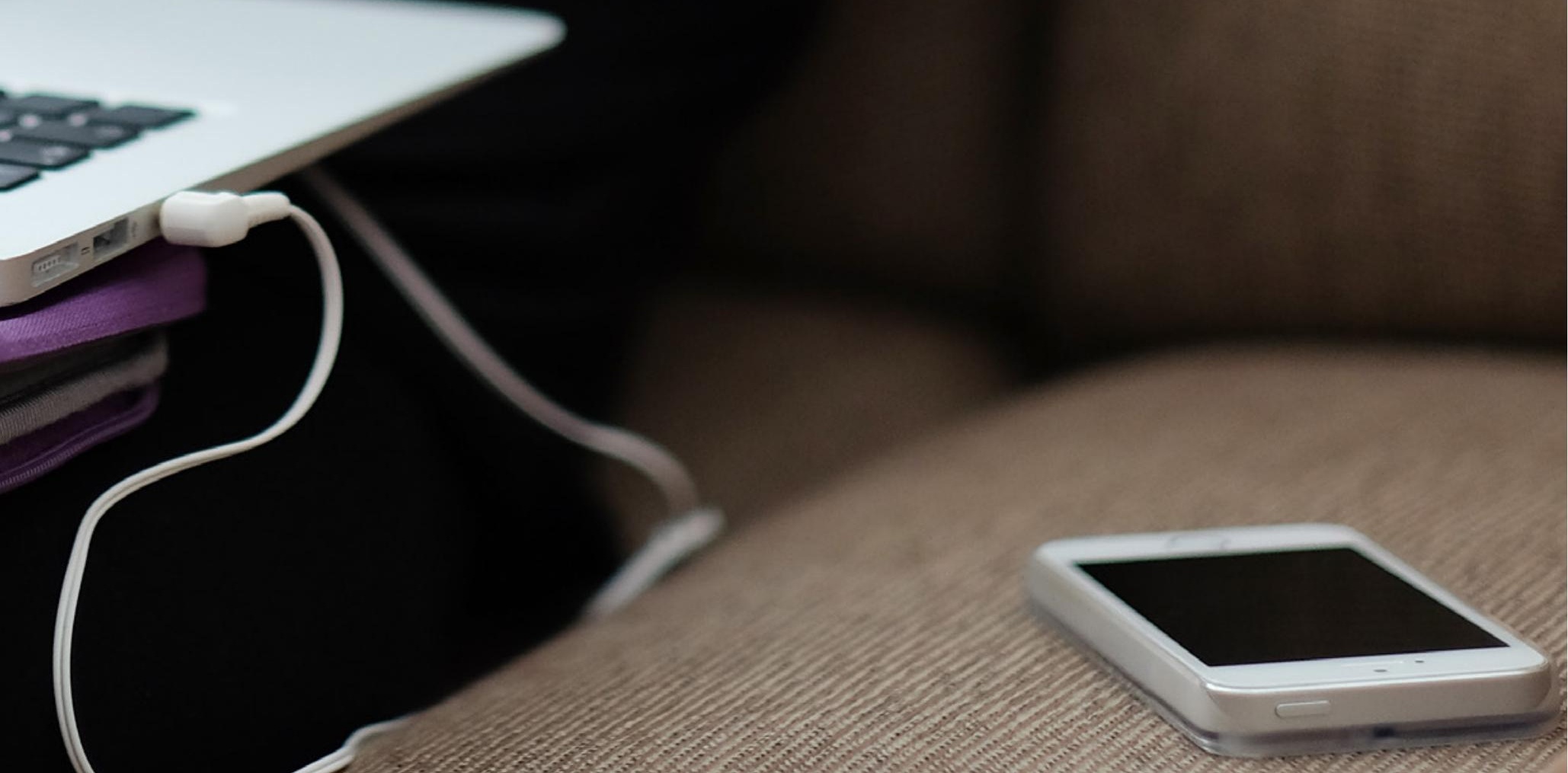





\section{Nordic eHealth benchmarking}

From piloting towards established practice

Hannele Hyppönen, Sabine Koch, Arild Faxvaag, Heidi Gilstad, Christian Nohr, Gudrun Audur Hardardottir, Hege Andreassen, Pernille Bertelsen, Maarit Kangas, Jarmo Reponen, Sidsel Villumsen and Vivian Vimarlund

TemaNord 2017:528 


\section{Nordic eHealth benchmarking}

From piloting towards established practice

Hannele Hyppönen, Sabine Koch, Arild Faxvaag, Heidi Gilstad, Christian Nohr, Gudrun Audur Hardardottir, Hege Andreassen, Pernille Bertelsen, Maarit Kangas, Jarmo Reponen, Sidsel Villumsen and Vivian Vimarlund

ISBN 978-92-893-4976-5 (PRINT)

ISBN 978-92-893-4977-2 (PDF)

ISBN 978-92-893-4978-9 (EPUB)

http://dx.doi.org/10.6027/TN2017-528

TemaNord 2017:528

ISSN $0908-6692$

Standard: PDF/UA-1

ISO 14289-1

(c) Nordic Council of Ministers 2017

Cover photo: unsplash.com

Print: Rosendahls

Printed in Denmark

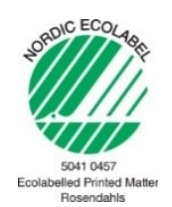

Although the Nordic Council of Ministers funded this publication, the contents do not necessarily reflect its views, policies or recommendations.

\section{Nordic co-operation}

Nordic co-operation is one of the world's most extensive forms of regional collaboration, involving Denmark, Finland, Iceland, Norway, Sweden, the Faroe Islands, Greenland, and Åland.

Nordic co-operation has firm traditions in politics, the economy, and culture. It plays an important role in European and international collaboration, and aims at creating a strong Nordic community in a strong Europe.

Nordic co-operation seeks to safeguard Nordic and regional interests and principles in the global community. Shared Nordic values help the region solidify its position as one of the world's most innovative and competitive. 


\section{Contents}

Abbreviations

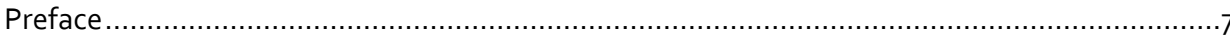

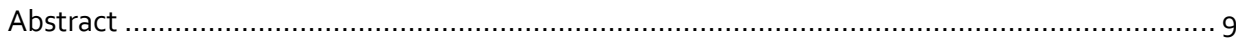

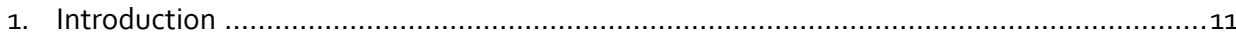

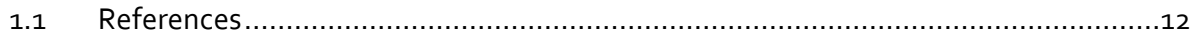

2. Nordic eHealth policies - what has changed since 2012? ........................................13

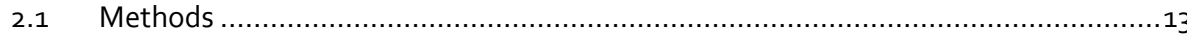

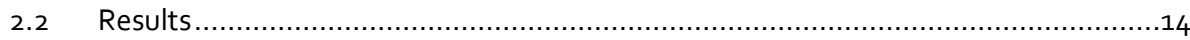

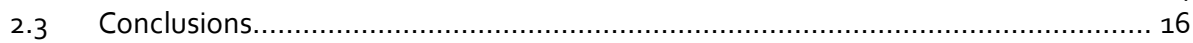

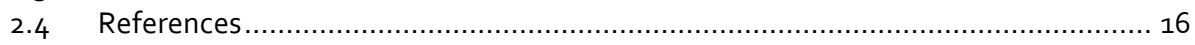

3. Governance systems for eHealth monitoring in the Nordic countries...........................17

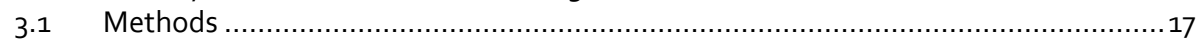

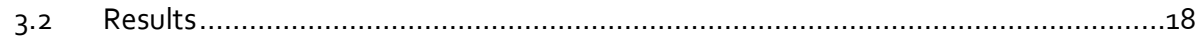

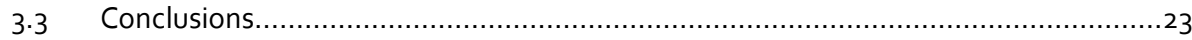

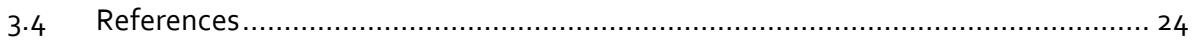

4. Making available the results of Nordic eHealth monitoring ...................................... 25

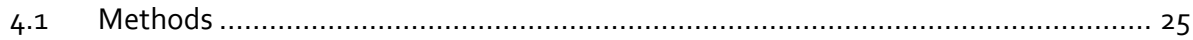

4.2 National reporting systems for eHealth indicators ....................................... 25

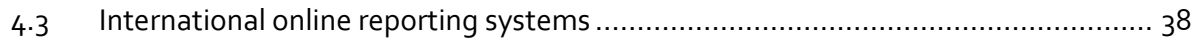

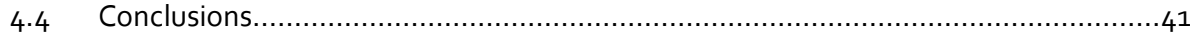

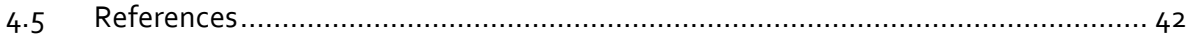

5. Common indicators for eHealth services: patients' and citizens' points of view............... 43

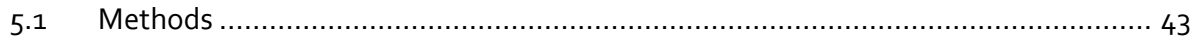

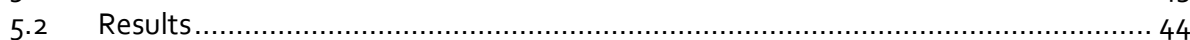

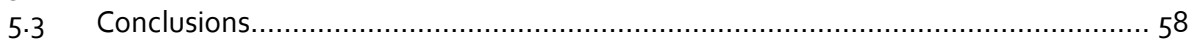

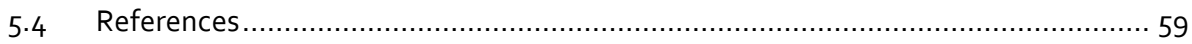

6. eHealth indicator work worldwide - steps in collaboration with the OECD, WHO and EU .. 61

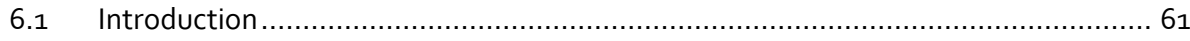

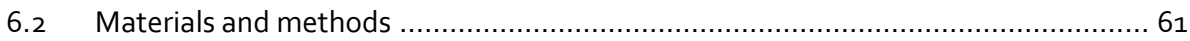

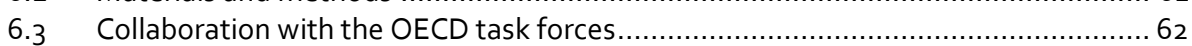

6.4 Overview of OECD Studies on eHealth vs. the EU eHealth action plan ................... 65

6.5 Analysis of ongoing and recently completed eHealth projects in the EU .................70

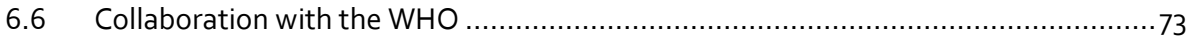

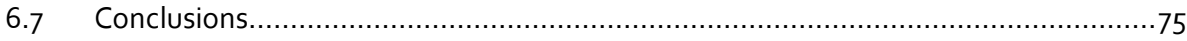

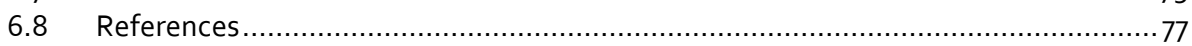

7. Discussion, conclusions and a way ahead ........................................................... 79

7.1 Monitoring implementation of the strategies is part of most of eHealth strategies ..79

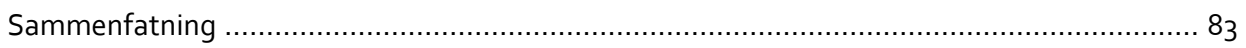





\section{Abbreviations}

- ATH: Vuxenbefolkningens hälsa, välfärd och service-survey

- AvoHILMO: Register of Primary Healthcare Visits

- COST: European Cooperation in Science and Technology

- eHealth: health services and information delivered or enhanced through the Internet and related technologies

- eHN: eHealth Network

- EHR: Electronic Health Record

- EU: European Union

- FP7: the European Union's Research and Innovation funding programme for 2007-2013

- GOe: Global Observatory for eHealth

- GP: General Practitioner

- HIE: Health Information Exchange

- HTA: Health Technology Assessment

- ICT: Information and Communication Technologies

- INERA AB: A company offering information technology support to the healthcare sector and operating national patient summary

- IT: Information technology

- IVR: Interactive Voice Response

- JAMIA: Journal of the American Medical Informatics Association

- JAseHN: Joint Action to support the eHealth Network

- Kanta: The Finnish national health information system

- KTH:Royal Institute of Technology, Stockholm

- MedCom: A non-profit organisation facilitating the cooperation between authorities, organizations and private firms linked to the Danish healthcare sector

- mHealth: Mobile health

- MMS: Multimedia Messaging Service

- MWP: the eHN's Multiannual Work Plan

- NCM: Nordic Council of Ministers

- NeRN: Nordic eHealth Research Network

- NGO: Non-Governmental Organisation

- NOMESCO: Nordic Medico-Statistical Committee 
- NOSOSCO: The Nordic Social Statistical Committee

- NPE: Nationell patient enkät

- NSE: Norwegian Centre for E-health Research

- NTNU: Norwegian University of Science and Technology

- OECD: Organisation for Economic Co-operation and Development

- PHR: Personal Health Record

- SALAR: The Swedish Association of Local Authorities and Regions

- SFMI: Svensk Förening för Medisinsk Informatik

- SMS: Short Message Service

- STePS: Project for National eHealth monitoring in Finland

- TeleHealth: distribution of health-related services and information. via electronic information and telecommunication technologies

- THL: National Institute for Health and Welfare

- UMO: platform used to access the platform

- UNICEF: United Nations International Children's Emergency Fund

- VB: Vårdbarometer

- VC: Videoconferencing

- WHO: World Health Organisation 


\section{Preface}

The Nordic countries have progressed far in the development and implementation of national health information systems. The differences in eHealth policies, architectures, and implementation create a fruitful basis for benchmarking and learning from each other.

The eHealth group established the Research Network to develop, test and assess a common set of indicators for monitoring eHealth in the Nordic countries, Greenland, the Faroe Island and Åland, for use by national and international policy makers and scientific communities to support development of Nordic welfare.

The Research Network published its first report in 2013, where a methodology was presented to generate eHealth indicators, and the first common indicators were tested. The second report, published in 2015, presented the benchmarking results of altogether 49 common Nordic health IT indicators, for which data were available for 48 inductors from at least some Nordic countries. As such, the report offered a unique view into the state of the art of health IT in the Nordic countries, into continuing work on health IT policies, and into support for high-performance health systems and quality and efficiency of health care and services.

This report is the third in a series of reports of work that started in 2012. One priority for the group during the period 2015-2017 has been to propose a long-term management of earlier work by exploring options for collecting, analysing, and publishing the benchmarking results and comparisons between the Nordic countries. Furthermore, the research network was to see how the network outcomes can be used in a European and OECD context. The third task was to identify common indicators that can be used to analyse and compare patients' and citizens' use and experiences of eHealth services.

This report illustrates possibilities, challenges and suggestions related to these topics. It offers important lessons to both policy makers and researchers in work towards Nordic and EU-wide data to support evidence-based eHealth policy. 



\section{Abstract}

The Nordic eHealth Research Network (NeRN) tasks, as a subgroup of the Nordic Council of Ministers (NCM) eHealth group in period 2015-2017 have been

- to propose a long-term management of earlier work by exploring options for collecting, analysing and publishing the benchmarking results and comparisons between the Nordic countries

- to see how the network outcomes can be used in a European and OECD context

- To identify common indicators that can be used to analyse and compare patients' and citizens' use and experiences of eHealth services.

The methods used were updating of the eHealth policy analysis from 2012, collection of information about reporting systems and their contents in the Nordic countries, analysing EU, WHO and OECD documents, and a comparison of the contents of the citizen eHealth surveys in the Nordic countries.

The eHealth policy analysis shows that there is a shift away from an emphasis on technical infrastructure towards an emphasis on governance and stakeholder involvement in all countries. Business support remains an important strategic target. The existing common eHealth indicators form a good basis for eHealth monitoring, although some updates are required. There are two issues that need to be resolved to pave the way to the long-term management of (increasingly log-based) eHealth benchmarking data in the Nordic countries: 1) decisions on governance of the eHealth benchmarking work and 2) collaboration between several different reporting systems within each Nordic country, including those with log and register-based data, to generate common reports that also include log- and register-based monitoring of eHealth outputs/outcomes/impacts.

Within the Nordic countries, the EU, WHO, and OECD, there is a shared understanding of the importance of and emphasis on eHealth benchmarking. There are very similar goals that form a good basis for collaborating on generating common measures. The Nordic countries as leaders in eHealth implementation are also quite advanced in the eHealth benchmarking efforts, and so joining forces to develop key indicators on common policy areas to be reported not only on Nordic but on EU-level for evidence-based policy making would serve all parties.

Analysis of the citizen surveys in the different Nordic countries showed that there is clearly a potential to develop common indicators in this area. There is a general interest in measuring effects and preferences regarding use and re-use of eHealth information, interact with health and social care and to, in parallel, increase patient 
empowerment. The existing survey tools offer a good basis for the development of a common model survey to monitor eHealth from the citizens' point of view.

Based on the results, five tasks have been proposed to the Nordic Council of Ministers eHealth group as possible roads ahead in the work towards an established eHealth benchmarking system to support evidence-based eHealth policy making in the Nordic countries. 


\section{Introduction}

The Nordic eHealth Research Network (NeRN) was established by the Nordic Council of Ministers (NCM) eHealth group in 2012. The objective was to develop, test, and evaluate a common set of indicators for monitoring eHealth in the Nordic countries, Greenland, Faroe Islands and Aaland, for use by national and international policy makers and scientific communities to support the development of Nordic welfare.

The results of the network's first Mandate period (2012-2013) were published in the Nordic Council of Ministers report (https://doi.org/10.6027/TN2013-522) (1). It contained a methodology for generating eHealth indicators by combining top-down and bottom-up approaches. It also tested the methodology with four common Nordic Indicators, measuring the availability of certain eHealth systems/functionalities (indicators 1, 2 and 4) and the use of particular functionalities (indicator 3 ).

The results of the network's second Mandate period (2013-2015) were also published in a Nordic Council of Ministers report (https://doi.org/10.6027/TN2015-539) (2).The publication extended the list of common Nordic eHealth indicators, reported lessons learned and recommendations to achieve efficient and easy-to-use benchmarking information. Benchmarking results were presented in the report on altogether 49 common eHealth indicators.

The aim of the network's third mandate period (2015-2017) has been to propose the long-term management of earlier work. The research network was to establish a system for collecting, analysing and publishing the effects and benefits of the investment in eHealth and the comparisons between the Nordic countries. Furthermore, the research network was to see how the network outcomes can be used in a European and OECD context. The third task was to identify common indicators that can be used to analyse and compare patients' and citizens' use and experiences of eHealth services. This publication reports the outcomes of the following three tasks:

1. Results on the establishment of a permanent system for collecting, analysing and publishing indicator data are presented in Chapters 2, 3 and 4. Chapter 2 presents an analysis of the most current Nordic eHealth policies, answering the question: how have the policies and top-down needs for eHealth indicators changed from 2012 to 2016 ? Chapter 3 depicts the results of the analysis of governance of systems of eHealth monitoring in the Nordic countries, answering the question: what is the basis for a permanent governance system for eHealth monitoring in the Nordic countries? Chapter 4 contains an analysis of online reporting systems on eHealth monitoring data in the Nordic countries and on a Nordic and European level, answering the question: what is the basis for a permanent reporting system of eHealth indicator data in order to make the results accessible to decision-makers and researchers? 
2. Results on defining indicators for eHealth services: patients' and citizens' points of view are presented in Chapter 5, answering the question: what is the basis for common monitoring of eHealth services from the citizen viewpoint in the Nordic countries?

3. Results on exploitation of the work in a European, WHO and OECD context are depicted in Chapter 6, answering the question: what is done internationally related to eHealth monitoring, and how can the NeRN work bring added value to eHealth indicator work globally?

The discussion and conclusions-chapter (Chapter 7) collates the lessons learned by answering these questions, and points the way ahead towards making comparable eHealth benchmarking as an integral part of eHealth governance in the Nordic countries.

\section{$1.1 \quad$ References}

(1) Hyppönen et al. (2013). Nordic eHealth Indicators. Organisation of research, first results and the plan for the future. TemaNord 2013:522. Copenhagen: Nordic Council of Ministers.

(2) Hyppönen et al. (2015). Nordic e-health Benchmarking. Status 2014 TemaNord 2015:539. Copenhagen: Nordic Council of Ministers. 


\section{Nordic eHealth policies - what has changed since 2012?}

According to the work plan, the first task - "Establishment of a permanent system for collecting, analysing and publishing of indicator data" - called for defining which eHealth indicators should be regularly monitored. In mandate period II, the 49 common indicators were based on the Nordic eHealth policies analysed in 2012, the OECD model survey, and national indicators available at that time. We needed to establish how accurately the defined indicators would still cover the new policies, and what potentially new indicator areas would emerge from the policies. This called for analysis of the current eHealth policies and their objectives, and for a comparison against those set in 2012 to detect changes in emphasis.

\subsection{Methods}

The method was a content analysis of the most current eHealth policy documents, and a comparison of the results against the policy analysis results of the first mandate period (2012-2013). All the Nordic countries published new eHealth strategies after 2012. The key objectives in the most recent eHealth policies needed to be identified to see how they had changed from the previous analysis.

Policies to be included in the analysis were obtained from each of the Nordic countries via their representatives in the Nordic ministry network (Table 1). No eHealth policy was obtained from Greenland, the Faroe Islands or Åland.

The Swedish, Norwegian and Danish eHealth policies (1-9) were analysed in their respective native languages. The Icelandic and Finnish policies were analysed using the official English versions of the documents. The policies were analysed with use of the HyperResearch (https://en.wikipedia.org/wiki/HyperRESEARCH) text annotation tool. Sentences and sections that contained statements about motivation for policy, the main strategic targets, actors and players, measures, plans and stakeholders involved were identified by reading and were then labelled with an appropriate code/tag. The code book from the analysis in 2012 was used as a starting point but expanded with codes that represented updated concepts from the new policies as these were read and annotated. Upon completion of coding by researcher 1 (AF), the code book was condensed in a second round of analysis and overlapping codes were merged. The condensed code book and resulting annotations was thereafter printed and reviewed by two other researchers ( $C N$ and $\mathrm{SV}$ ). 
Table 1: Nordic eHealth policies included in the policy analysis update

$\begin{array}{ll}\text { Country } & \text { Policy (Year published) } \\ \text { Denmark } & \text { Local and digital - An interconnected Denmark }{ }^{1} \text { (2016). [Lokal og Digital - Et sammenhængende } \\ & \begin{array}{l}\text { Danmark] (1) } \\ \text { Action plan to improve the use of health data (2015). [Handleplan for bedre brug av Sundhedsdata] (2) } \\ \text { Agreements on the finances of the municipalities and regions }{ }^{1} \text { (2015) [Aftaler om den kommunale og } \\ \text { regionale økonomi] (3) }\end{array} \\ & \text { Information to support well-being and service reneval - eHealth and e-social strategy 2020 (2015) (4) } \\ \text { Finland } & \text { National eHealth Strategy 2016-2020 (2016) (5) } \\ \text { Iceland } & \text { One citizen - one health record (2012). [Én innbygger - én journal] (6) } \\ \text { Norway } & \text { National action plan for eHealth (2014). [Nasjonal handlingsplan for e-helse]. (7) } \\ \text { Sweden } & \text { EHealth 2010 (2010). [Nationell eHälsa 2010] (8) } \\ & \text { Vision eHealth 2025 (2016). [Vision e-Hälsa 2025] (9) }\end{array}$

Note: 1 Policy document not specific for the healthcare sector.

Figure 1 depicts the coding work conducted with the analysis programme.

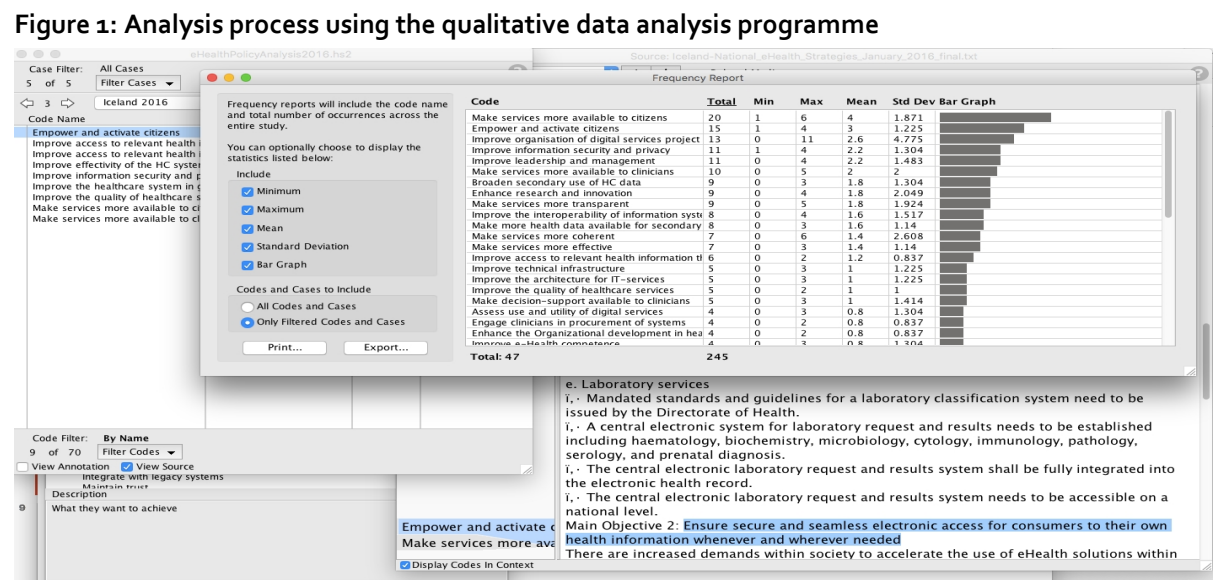

\subsection{Results}

The current eHealth policies from the Nordic countries reflect the large accomplishments of Nordic eHealth policy work in the past. All the countries have working versions of eHealth systems and services in most parts of the healthcare sector. The current policies reflect a growing awareness of the huge enabling and transformative power that lies within well-designed and integrated eHealth services, 
while at the same time recognizing that the largest benefits from eHealth are still to be reaped.

The key strategic targets in the most recent eHealth policies reflect a continuous focus on empowering and activating citizens. From building citizen-centred eHealth services that provide access to knowledge resources and enable the citizen to see his/her prescriptions or to book appointments online, many eHealth policies now focus on making the citizens' digital interface his or her preferred channel for interacting with the healthcare system, i.e. that he or she can be provided with healthcare services through that very same digital interface. Hence, the eHealth policies reflect an aim to position eHealth services between the patient and the healthcare system. A third strategic target is centred around making services more integrated and available. This can be seen as a reaction to the practice of the past of building health information silos, the situation that arises when the same information is archived in many different systems and is presented with similar functionality. Related to this is a broader stakeholder picture and a strategic target to make data available to all stakeholders without jeopardising privacy and trust.

Making systems more usable and building eHealth literacy (i.e. the competencies required for using and for making sense of the applications) reflect the Nordic countries continuous emphasis on healthcare professionals, and on building eHealth systems that make health personnel better at doing their work by easing their interaction with the systems. A sixth strategic target is reaping economic benefits from many years of investing in eHealth. This aspect is particularly important in the Finnish eHealth policies, but is also reflected in the Danish and Norwegian policy documents. Finally, reflecting the continued interest in improving healthcare services by building and implementing eHealth systems and services, becoming better at organising eHealth projects is an important objective in the policy documents. This aspect is most highlighted in the Swedish eHealth policy documents.

Figure 2 depicts the change in emphasis in the main strategic targets between 2012 and 2016.

Figure 2: Overall strategic profiles from 2012 to 2016

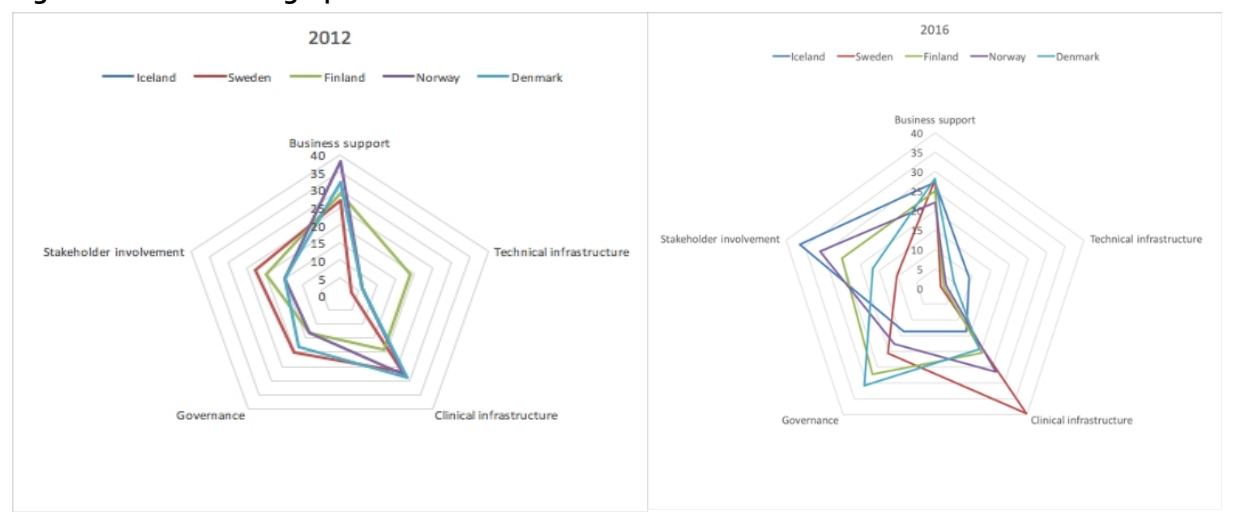


As can be seen from Figure 2, a slightly more "rounded" overall profile emerges from the 2016 policy analysis than in 2012. In general, there is a shift away from emphasising on technical infrastructure towards emphasising governance and stakeholder involvement in all countries. Stakeholder involvement is prominent especially in Iceland. Business support remains an important strategic target. Emphasis on clinical infrastructure is most prominent in Sweden.

\subsection{Conclusions}

Based on this updated policy analysis, indicators should be developed on the following aspects of eHealth systems and services:

- The availability, update-ability, trustability and understandability of eHealth services from the end-user perspective (both clinician and citizen).

- Use and utility of the eHealth services both from end-user and health system perspectives.

- Establishing maintenance, availability, use and utility of shared information infrastructures from the perspectives of end-users, leaders, researchers and innovators.

- Availability and utility of eHealth enabled healthcare service redesigns.

\section{$2.4 \quad$ References}

(1) Local and digital - An interconnected Denmark (2016) [Lokal og Digital - Et sammenhængende Danmark].

(2) Action plan to improve the use of health data (2015) [Handleplan for bedre brug av Sundhedsdata] Denmark.

(3) Agreements on the finances of the municipalities and regions1 (2015) [Aftaler om den kommunale og regionale økonomi] Denmark.

(4) Information to support well-being and service reneval - eHealth and e-social strategy 2020 (2015) Finland.

(5) National eHealth Strategy 2016-2020 (2016) Iceland.

(6) One citizen - one health record (2012) [Én innbygger - én journal] Norewy.

(7) National action plan for eHealth (2014) [Nasjonal handlingsplan for e-Helse] Norway.

(8) EHealth 2010 (2010) [Nationell eHälsa 2010] Sweden.

(9) Vision eHealth 2025 (2016) [Vision e-Hälsa 2025] Sweden. 


\section{Governance systems for eHealth monitoring in the Nordic countries}

The task: "Establishment of a permanent system for collecting, analysing and publishing of indicator data" also called for analysis of the governance of the eHealth monitoring activities in the Nordic countries. The Nordic Council of Ministers eHealth group expected suggestions for innovation of eHealth strategies and the development of practices for the production of systematic and comparable eHealth benchmarking data in the Nordic countries. This could consequently also be relevant for eHealth monitoring within the EU and OECD countries.

This chapter thus answers the following questions: What is the current governance ${ }^{2}$ system for eHealth monitoring in the Nordic countries? What are the needs regarding a permanent eHealth monitoring system in the Nordic countries?

\subsection{Methods}

To answer the question, an analysis of the ways for organising the collection, analysis and reporting of eHealth indicator data was called for. This was conducted by posing the following questions to the Nordic eHealth indicator group delegates:

- How is eHealth monitoring visible in the country's eHealth strategy?

- How is the eHealth indicator data collection organised?

- How is the data collection and reporting funded?

- How is eHealth monitoring data made available to policy makers and researchers?

Analysis of the reporting systems provided a wealth of data, reported in Chapter 4. The responses to the three first questions were reported by each of the network members, and collected and documented in each of the working group meetings (September 2015, March 2016, September 2016 and February 2017) to illustrate the development in each of the Nordic countries during the mandate period.

2 Governance means "establishment of policies, and continuous monitoring of their proper implementation, by the members of the governing body of an organization." http://www.businessdictionary.com/definition/governance.html 


\section{$3.2 \quad$ Results}

\subsubsection{Nordic systems for the governance (organizing) of eHealth indicator work}

The governance system for eHealth monitoring activities varies in different Nordic countries. The Danish, Finnish, Swedish and Norwegian eHealth policy documents describe to some extent plans to assess the use, effects and benefits of IT-services, but no concrete actions are suggested. The Icelandic eHealth policy document includes procedures to obtain data on access to and usage of eHealth. The Finnish eHealth policy explicitly states that usability monitoring will be continued and extended from physicians to other professional groups

The key aspects of the governance systems are collated in Table 2, and described in more detail in the text.

\section{Governance of eHealth monitoring in Finland}

The policy analysis revealed the following policy goal in Finland related to monitoring the implementation of the eHealth strategy published in 2015 (1).

\footnotetext{
"After the adoption of the strategy, an implementation plan will be produced in cooperation with the implementation of the social welfare and health reform and stakeholders. At this stage, responsibilities for the measures will be assigned and a schedule will be produced for their implementation, and indicators for monitoring the implementation will be established. Priority will be given to measures essential for the social welfare and healthcare services reform. Parties responsible for the implementation will also prepare an implementation plan and obtain the necessary funding in cooperation with the appointed parties. Almost all measures will require broad cooperation between different actors. The Advisory Board for Information Management in Social and Healthcare will supervise and evaluate the strategy implementation. Regular follow-up reports will be published on strategy implementation."
}

The strategy specifically mentions one target for monitoring: the usability of patient data systems from the viewpoint of professionals:

"Usability surveys will continue to be conducted on a regular basis, and their targeting at professional groups in social welfare and healthcare will be increasingly comprehensive."

In Finland, the eHealth monitoring data collection has been co-funded by the Ministry of Social Affairs and Health and by research institutes on a project-basis from 2003 onwards, when the first eHealth availability and use-surveys were conducted targeted to healthcare organisations. The project has been led by the National Institute for Health and welfare (THL). The project period has usually been $2-3$ years, within which the data have been collected, analysed and reported. The external funding has covered approximately half of the costs of data collection and reporting, with participants covering the other half. In 2013, the various monitoring projects were for the first time collated under one umbrella project (STePS 2013-2016) (2). The eHealth strategy was published in 2015, and the STePS-project outcomes were reported as measures of the baseline situation prior to strategy implementation. 
In 2016, the STePS-project received funding to continue for the next 3 years (20162019). In 2017, data collection will for the first time include a national usability survey of nurses, data collection from the Kantalogs, as well as building a dynamic online reporting system for easy access and dynamic reporting. The reporting system will be a platform for automatic updates and publication of specified Kantalog data and later also for outcome/impact data from different national registers. The reporting system will be built to monitor the progress of the strategy implementation.

\section{Governance of eHealth monitoring in Sweden}

In Sweden, the National High-Level Group for eHealth is responsible for taking a holistic view of strategy implementation and for monitoring how well the various national projects deliver in relation to the action plans drawn up by each actor respectively. According to the strategy:

The organisations behind National eHealth agree on the need to strengthen national monitoring of the deployment and use of existing technology and services. The full potential of coherent eHealth services will only be realised once they are extensively implemented and used, which underlines the importance of transforming these national projects into widely implemented management tools more rapidly than is happening at the moment. During 2010 and 2011, the High-Level Group for National eHealth intends to initiate a project to jointly review the national management of the work to implement the strategy and look at models for how to monitor implementation and evaluate its effects. The results of this project will be presented by the end of 2011. 
Table 2: Key aspects of the governance systems of eHealth monitoring in the Nordic countries

\begin{tabular}{|c|c|c|c|c|c|}
\hline Country & $\begin{array}{l}\text { eHealth } \\
\text { monitoring } \\
\text { mentioned in the } \\
\text { strategy }\end{array}$ & $\begin{array}{l}\text { Monitoring data } \\
\text { collected }\end{array}$ & Collection organisation & Collection cost & Funding mechanism \\
\hline Finland & $\begin{array}{l}\text { yes (generic and } \\
\text { usability) }\end{array}$ & $\begin{array}{l}\text { Surveys: 1) eHealth } \\
\text { availability + use, 2) } \\
\text { eWelfare availability } \\
\text { +use, } 3 \text { ) eHealth } \\
\text { usability (physicians } \\
\text { and nurses). } 4 \text { ) Citizen } \\
\text { experiences } \\
\text { Kanta log data }\end{array}$ & $\begin{array}{l}\text { A project led by THL. Partners: physician and } \\
\text { nurse associations, University of Oulu, } \\
\text { University of Eastern Finland, University of } \\
\text { Aalto, Social Insurance Institution }\end{array}$ & $\begin{array}{l}\text { EUR } 350,000 \\
\text { (ca. EUR 80,000 } \\
\text { per survey) }\end{array}$ & $\begin{array}{l}\text { Project-based, } \\
\text { funded } 50 \% \text { by } \\
\text { Ministry, } 50 \% \text { by } \\
\text { participants, } 3 \text {-year } \\
\text { contracts }\end{array}$ \\
\hline Sweden & $\begin{array}{l}\text { yes (generic, } \\
\text { availability, use, } \\
\text { benefits) }\end{array}$ & $\begin{array}{l}\text { Organisational surveys } \\
\text { (yearly) about eHealth } \\
\text { availability } \\
\text { Log data }\end{array}$ & $\begin{array}{l}\text { National data collection: Swedish Association } \\
\text { of Local authorities and Regions (SALAR) } \\
\text { (organisational surveys; eHälsomyndigheten } \\
\text { (log data medication); Inera and } 1177 \text { (log data } \\
\text { eHealth services) } \\
\text { Different surveys and log data collection at } \\
\text { regional level }\end{array}$ & Not available & Not available \\
\hline Norway & & & $\begin{array}{l}\text { No systematic eHealth monitoring in } \\
\text { Norwegian healthcare since } 2010 \text { and citizen } \\
\text { surveys since } 2013 \text {. However, there is an } \\
\text { ongoing project at the Directorate for eHealth } \\
\text { for planning eHealth monitoring on a national } \\
\text { level. The aim of the project is to examine } \\
\text { various concepts for national monitoring of } \\
\text { eHealth, give recommendations on concepts } \\
\text { and to plan its implementation. The monitor } \\
\text { shall also follow eHealth trends over time and } \\
\text { enable international comparison. } \\
\text { (https://ehelse.no/e-helse-monitor) }\end{array}$ & & \\
\hline Denmark & $\begin{array}{l}\text { Yes (reliability and } \\
\text { usage) }\end{array}$ & $\begin{array}{l}\text { National indicators: } \\
\text { Log data from different } \\
\text { systems and regions } \\
\text { Healthcare professional } \\
\text { survey } \\
\text { Citizen survey }\end{array}$ & $\begin{array}{l}\text { Each region sends data on primary care related } \\
\text { indicators to Danish Regions, who collate } \\
\text { them. SDS collate all data. } \\
\text { Data on indicators regarding transactions } \\
\text { between primary and secondary care is } \\
\text { provided by MedCom (independent, yet } \\
\text { government financed organization). } \\
\text { Data regarding Shared Medication records is } \\
\text { provided by Trifork (Private software } \\
\text { company) } \\
\text { Municipal data and data on national services } \\
\text { are retrieved directly by } \\
\text { Sundhedsdatastyrelsen (SDS -Government } \\
\text { organisation). } \\
\text { University } \\
\text { University }\end{array}$ & $\begin{array}{l}\text { Costs regarding } \\
\text { data collection } \\
\text { not specified } \\
\text { and not } \\
\text { reimbursed }\end{array}$ & $\begin{array}{l}\text { Each data collecting } \\
\text { organization funds } \\
\text { their own data } \\
\text { extraction. }\end{array}$ \\
\hline Iceland & $\begin{array}{l}\text { Yes, access and } \\
\text { usage }\end{array}$ & $\begin{array}{l}\text { National indicators: } \\
\text { 1. Log data } \\
\text { 2. eHealth survey on } \\
\text { usability ( : physicians } \\
\text { and nurses) } \\
\text { 3. eHealth survey on } \\
\text { citizen experiences }\end{array}$ & Directorate for Health & $\begin{array}{l}\text { Costs regarding } \\
\text { data collection } \\
\text { not specified } \\
\text { and not } \\
\text { reimbursed }\end{array}$ & $\begin{array}{l}\text { No additional } \\
\text { funding. }\end{array}$ \\
\hline
\end{tabular}


In Sweden, usability of eHealth has been surveyed by KTH by Users Award (3) in 2004 and 2010 from a sample of doctors, nurses and assistants, while eHealth availability and use has been surveyed yearly from organisations since 2000 by INERA (http://www.inera.se/). There has been no national coordination regarding data collection on eHealth strategy implementation; SALAR (The Swedish Association of Local Authorities and Regions) organises the collection of organisational surveys in the county councils (4) and the collection of a patient survey "vårdbarometer" (http://vardbarometern.nu/) (only includes very few eHealth indicators to date); eHälsomyndigheten (https://www.ehalsomyndigheten.se/) has log data regarding medication and 1177 Vårdguiden (http://www.1177.se/) has some log data regarding citizen eServices.

In the autumn of 2016, Ministry of Social Affairs gave some support to the SFMI to continue work based on the NeRN work to disseminate results and develop the Swedish patient survey and make recommendations on how Sweden should collect the data (5).

\section{Governance of eHealth monitoring in Norway}

According to the Norwegian eHealth action plan 2014-2016, stronger national governance, prioritization and coordination of ICT development in the healthcare sector is one of the priority areas in Norway (6).

The eHealth policy documents state the following in relation to the governance of eHealth:

Good use of the opportunities provided by information technology is vital for achieving the health policy objectives. The White Paper St. 9 (2012-2013) "One citizen - one record- digital services in healthcare" defines the goals and shows the direction for the development of comprehensive ICT systems for healthcare so that the health information follows the patients. ICT systems will be based on the patients "and the services" needs while confidentiality and privacy are protected. The digital services should be comprehensive and user-friendly. Universal Design will pave the way so that as many as possible can take the services into use. In this context it will be important to focus on the consequences of possible digital divides and safeguarding the part of the population that often fall outside the possibilities of the digital age. The White Paper 9 "One citizen - one record" defines three overarching goals for ICT development in the health and care sector:

- Health professionals should have easy and secure access to patient and user information

- Citizens will have access to simple and secure digital services

- Data should be available for quality improvement, health monitoring, management and re-search (The National Action Plan for eHealth in Norway) (7).

In Norway, eHealth monitoring data has been collected by NTNU The Norwegian University of Science and Technology from doctors, nurses and assistants on a sample basis in 2008 and on actual use of eHealth systems in 2010, as well as by Norwegian Centre for eHealth Research (previously the National Center for Telemedicine) from citizens on experiences of eHealth services (2000, 2001, 2003, 2005, 2007, 2013, representative stratified population sampling). The recently established Directorate for eHealth received a mandate from The Ministry of Health and Care Services to do 
eHealth monitoring. It has given the NSE a mandate (with funding) to develop concepts for monitoring the attainment of eHealth policy goals. From 2017 there will be systematic monitoring. The organisation to actually collect and report the data has not been selected.

\section{Governance of eHealth monitoring in Denmark}

The Danish eHealth strategy has eHealth governance as one of the focus areas. The section on governance states that:

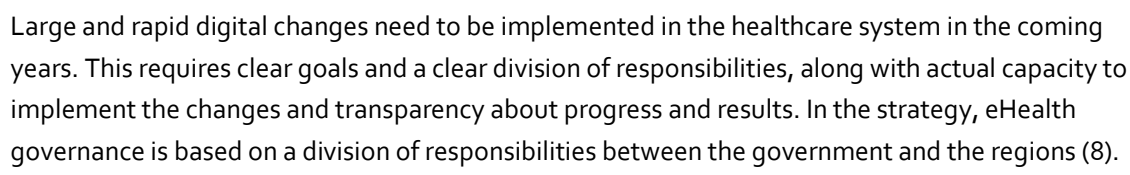

The strategy also states that:

In connection with the budget agreements for 2014, the Danish government, Local Government Denmark, and Danish Regions agreed to apply a series of indicators to report and follow up efforts. These indicators include:

Regions

1. Use of the Shared Medication Record: Percentage of medication-reconciled Shared Medication Records per discharge.

2. Use of note systems: Percentage of patients for whom recording has been completed at discharge.

Central government

1. Reliability of national health registries and infrastructure solutions, such as the Shared Medication Record, the National Service Platform, and the National Patient Registry.

2. Traffic figures for the National Service Platform.

Municipalities

1. Use of MedCom messages.

2. Percentage of relevant citizens covered by telemedical ulcer assessment.

The strategy presents examples of statistics from MedCom on HIE usage and from www.ssi.dk/nsi on the use of the shared medication record.

In addition to these activities, the Danish Centre for Health Informatics, at Aalborg University, has conducted an annual survey of health professionals and a biannual survey of citizens' use of health IT. Log data of citizens' use of e-record has been accessed through the national portal. This work has not received any external funding. 
Governance of eHealth monitoring in Iceland

In Iceland, The Directorate for Health both publishes the eHealth strategy (9) as well as monitors its implementation. According to the Icelandic National eHealth strategy 2016-2020, the emphasis is on integrated and interconnected health information systems where health professionals can seamlessly exchange meaningful health information. The strategy identifies four main goals:

1. Secure and seamless access for health professionals to patient information whenever and wherever needed.

2. Secure and seamless electronic access for consumers to their own health information whenever and wherever needed.

3. Ensure security and quality of health information within electronic health records.

4. Enhancement of electronic health record data retrieval and information dissemination.

The strategy also states that:

Electronic health records need to support data retrieval for outcome measures, quality monitoring, continuous quality improvement and scientific research.

The Directorate for Health has been monitoring national usage of ePrescriptions, national immunization data, interconnected electronic health records, and the citizen health portal through log data, since those projects were launched within the country, and continues to do so, on a monthly basis.

Monitoring of the common eHealth indicators has been conducted by the Directorate for Health in the context of the NeRN project. The first national survey in Iceland to measure physician and nurse eHealth usability and experiences was conducted in 2014. The surveys will continue to be conducted on a regular basis.

\subsection{Conclusions}

The following observations can be made from the governance systems of eHealth monitoring activities in the Nordic countries:

- Monitoring of the implementation of the strategies is included in most of the eHealth strategies.

- The overall quality of strategic monitoring goals varies, from generic goals for planning the monitoring, to stating individual indicators and the responsible actors.

- Organisation and funding mechanisms for monitoring the strategy implementation vary; costs are not in all cases covered. In practice, monitoring has been either project-based with related funding, arranged as self-organised 
and -funded activity, or to some extent, mandated to an organisation on a permanent basis.

- The clear connection between eHealth strategy goals and measures for actual monitoring activities is not in all cases necessarily visible.

A governance system for collection of data to monitor the eHealth strategy implementation is a prerequisite for the provision of systematic, comparable monitoring data for benchmarking and leaning. For this, a sustainable model for governance of eHealth monitoring in the Nordic countries needs to be developed.

\subsection{References}

(1) Finnish eHealth strategy (2015):

https://www.julkari.fi/bitstream/handle/10024/125955/URN_ISBN_978-952-00-3575-

4.pdf? sequence $=1$

(2) STePS (2013-2016): https://www.thl.fi/en/web/information-management-in-social-welfareand-health-care/what-is-information- management-/follow-up-of-the-information-systemservices-in-social-welfare-and-health-care

(3) Vard IT-rapporten (2010): https://www.vardforbundet.se/siteassets/engagemang-ochpaverkan/sa-gor-vi-varden-battre/vard-it-rapporten-2010.pdf

(4) The Swedish Patient Survey: http://www.inera.se/OM-OSS/styrdokument_rapporter/

(5) Regjeringskanselliet (2017):

http://www.regeringen.se/pressmeddelanden/2016/o8/internationella-e-halsoinsatser-skajamforas/

(6) The Norwegian Directorate for eHealth (2016): National Governance for eHealth in Norway. https://ehelse.no/Documents/E-

helsekunnskap/National_Governance_eHealth_Norway_Kristin_Bang.pdf

(7) The Norwegian Directorate for eHealth (2016): The Norwegian eHealth action plan 2014-2016; https://ehelse.no/Documents/Nasjonale\%2oprosjekter/Nasjonal\%2ohandlingsplan\%2ofor\%2oehelse.pdf

(8) The Danish eHealth Strategy (2013): http://www.sum.dk/ /media/Filer\%20-

\%20Publikationer_i_pdf/2013/Making-eHealth-work/Making\%2oeHealth\%2oWork.ashx

(9) The Icelandic eHealth Strategy (2016):

http://www.landlaeknir.is/servlet/file/store93/item28955/National_eHealth_Strategies_Januar y_2016_final.pdf 


\section{Making available the results of Nordic eHealth monitoring}

Making commonly agreed indicator data available to policy makers and researchers was one of the goals of the NeRN network for the mandate period 2015-2017. To this end, the network has sought solutions for the publication of the recommended common Nordic eHealth indicators. Both national publishing channels and international online publication systems have been reviewed.

\subsection{Methods}

The following methods were used to answer the question on how the results of commonly agreed indicators can be made easily accessible by policy makers/others:

- A query of current online national eHealth monitoring data reporting systems in the Nordic countries was conducted in each of the network meetings, using the network members as informants.

- Options for international reporting were reviewed via information available on the Internet about Nomesco and Eurostat.

- The need for a common reporting system was considered in light of the eHealth monitoring governance systems to identify gaps and generate suggestions for improvement.

\subsection{National reporting systems for eHealth indicators}

This chapter describes current online reporting systems in each Nordic country for making eHealth indicator data available to decision-makers and researchers. 


\subsubsection{Finland}

\section{Kanta reporting}

In Finland, there are at present two online systems that host at least some eHealth indicator data. The first current host for eHealth indicator data is the national health information system (Kanta). This hosts statistics on the diffusion and use of national health information services http://www.kanta.fi/fi/web/ammattilaisille/tilastot. The data are real time and available in Finnish, Swedish and English. The statistics behind the figures are not openly available (Figure 3 ).

Figure 3: Example (in Swedish) of the online reporting of Kanta statistics

\begin{tabular}{l} 
WEBBSKOLA OM DET \\
ELEKTRONISKA RECEPTET \\
WEBBSKOLA OM \\
PATIENTDATAARKIVET \\
BEGÄRAN OM \\
INFORMATION FÖR \\
VETENSKAPLIG FORSKNING \\
VANLIGA FRÄGOR \\
ANVISNINGAR VID \\
STÖRNINGAR \\
\hline STATISTIK \\
\hline ORDLISTA \\
MATERIALBANK \\
KOMMUNIKATION \\
KONTAKTINFORMATION
\end{tabular}

\section{Statistik}

Statistiken i bilder

Det elektroniska receptet

Ordinergde och expedierade elektroniska recept under det senaste halvảret (klicka pả bilden för

att forstora den):

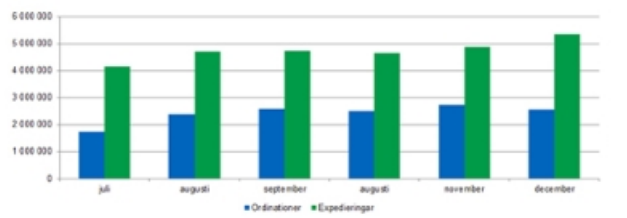

Ordinerade och expedierade elektroniska recept per månad:

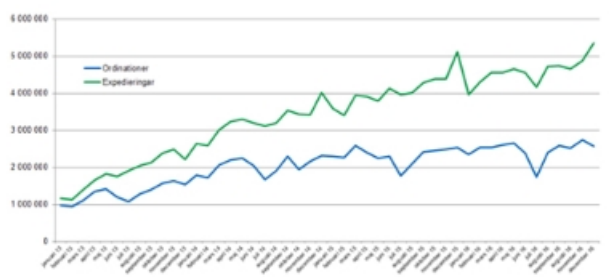

(C) Kanta Extranät

The following statistics are published on the website:

- No. of electronic prescriptions made and dispensed over the past six months.

- No. of electronic prescriptions made and dispensed monthly.

- No. of electronic prescriptions made and dispensed yearly.

- No. of documents archived in the Kanta system monthly.

- No. of persons whose documents have been archived monthly.

- No. of consents made monthly.

- No. of logins to Omakanta (citizens view to their data in the Kanta-system).

- No. of different persons having used Omakanta. 


\section{THL reporting}

The second reporting system is the online database reporting system of the National Institute for Health and Welfare (THL). The system is hosting an increasing amount of statistical and survey data, and making it available for flexible use online. (www.thl.fi/tikuinstructions). One set of statistics directly relevant for monitoring eHealth outcomes is the AvoHILMO statistics. AvoHILMO (Register of Primary Healthcare Visits) includes updated (updates every night automatically from EHRsystems) statistical entries of realized primary care outpatient care service events depicting the use of services (1). Statistics are collected for every visit. The quality of documenting the visit details is dependent on the professional that makes the entries in the care situation. It has been estimated that the quality of documenting the type of contact (electronic/ non-electronic) still varies. With good quality data, the AvoHILMO statistics could be used to assess usage of electronic visits as well as the reduction of unnecessary face-to-face-visits (one anticipated outcome of specific eHealth services). The current measures in the AvoHILMO online report (2) are:

- No. of visits (weakly update).

- No. of clients.

- No. of visits per clients.

- No. of visit per population.

The data can be viewed:

- By visit year (since 2014) and month.

- By service producer (listing each individual primary care service provider or total), grouped by region.

- By professional group.

- By service type visited.

- By visit urgency.

- By type of contact used in the visit:

- Documentation without patient contact.

- Letter.

- Consultation.

- Home visit.

- Visit at healthcare office.

- Other contact type.

- Telephone contact.

- Visit at hospital.

- Electronic contact.

- Occupational health visit (at workplace). 
Visit by electronic contact is defined as an individual examination, care or counselling provided by email, Internet, text messages or videoconferencing. The data for these statistics are real time and openly available currently in Finnish (and partially in Swedish) (Figures 4-5).

Figure 4: An example of dynamic reporting of AvoHILMO statistics

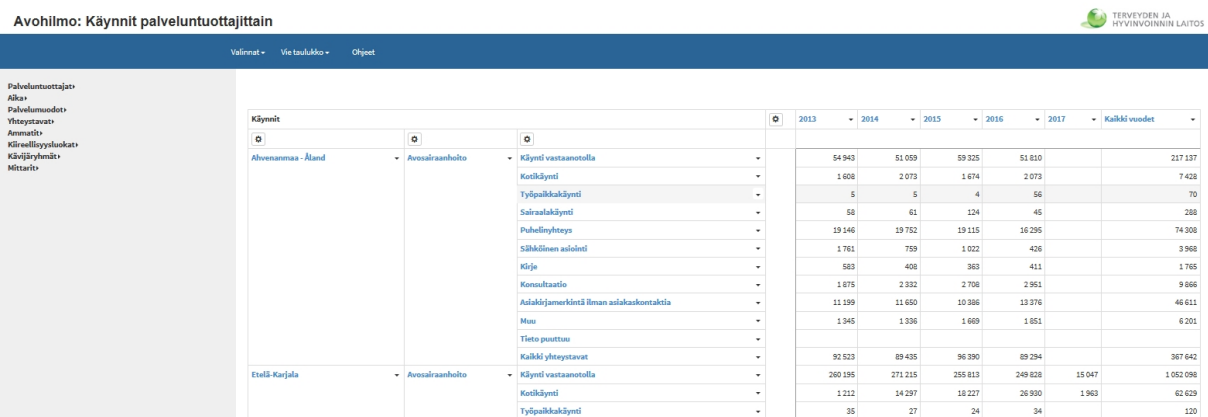

In addition to the dynamic database report, there are ready-made dynamic graphics where you can select and compare individual measures in selected dimensions in graphical format, depicting e.g. Proportion of visits with an ICD-coded and external reason; Proportion of visits with registered measures, or Time series of electronic visits (depicted in Figure 5)

Figure 5: An example of the AvoHILMO graphical report

TERVEYDEN JA
HYVINVOINNIN LAITOS

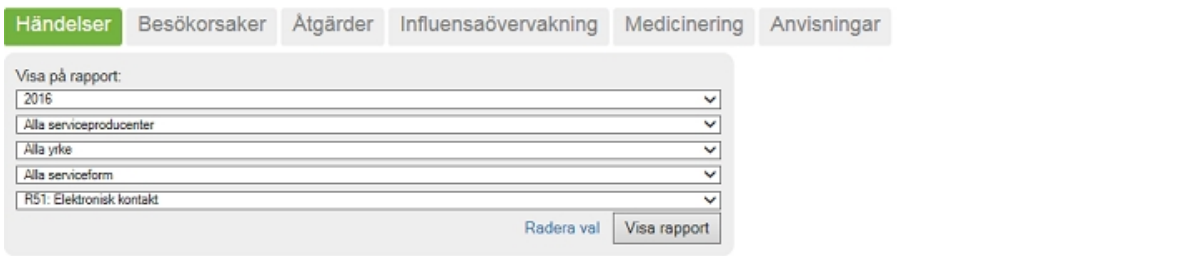

Genomforda besök

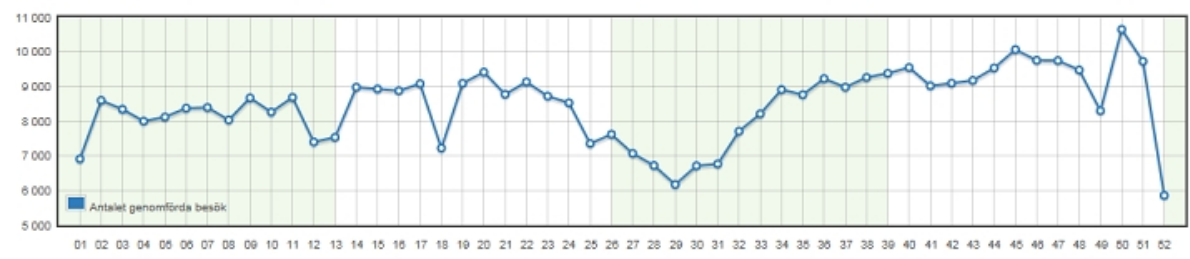

Besok per yrkesgrupp

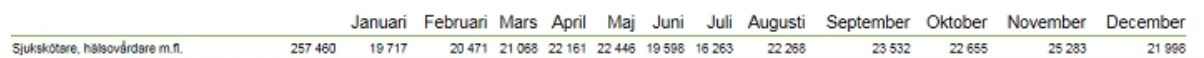

The THL dynamic reporting system is also exploited in the development of online reporting of the eHealth monitoring data (3). Data will include results from organisational, professional and citizen eHealth surveys, as well as Kanta log data. In the future, other register data can also be exploited to develop eHealth outcome 
indicators. The online reporting of the eHealth monitoring results will be structured according to the six Finnish eHealth strategy's main target areas, with indicators reflecting the objectives of the strategy:

1. Citizens as service users - doing it yourself.

2. Professionals - smart systems for capable users.

3. Service system - effective utilisation of limited resources.

4. Refinement of information and knowledge management - knowledge-based management.

5. Steering and cooperation in information management.

6. Infostructure - ensuring a solid foundation.

The strategic goals for the first target area are:

- Citizens are using online services and produce data for their own use and for professionals. Citizens are able to use the online services of the service providers no matter where they live. Information produced and maintained by the citizens themselves is utilised in the planning and implementation of treatment and services to the extent permitted by the citizen.

- Reliable information on wellbeing and services supporting its utilisation are available and assist citizens in life management and in promoting their own wellbeing or that of their family and friends. Online self-management services and information management associated with them may support the prevention of health problems, self-assessment of the need for services, and independent coping.

- Information on the quality and availability of services is available in all parts of Finland and can be used in the selection of the service provider. Reliable and comparable information on different alternatives and service providers increases freedom of choice.

These objectives of the first target area have been transformed into the following categories of measures:

- Availability of eHealth services to citizens: Proportion of organisations in each municipality offering different eHealth and eWelfare services to citizens. (Data will be taken from surveys of health and social care organisations). Proportion of different eHealth and eWelfare services are available (Data will be calculated from population statistics).

- Ability of citizens to use online services: Proportion of citizen survey respondents with elD for electronic services, Proportion of respondents with technology and competence to use basic eHealth services independently. 
- Usage of eHealth services by citizens: Proportion of citizen survey respondents having used different eHealth and eWelfare service functionalities by type of contact (visit, telephone, electronic).

- Experienced benefits of eHealth services: Proportion of respondents having saved visits by using key eHealth functionalities, Estimated nr. of visits saved via eService use by functionality.

- Experienced barriers to eHealth service use: Proportion of respondents having experienced barriers to eHealth use (by barrier type).

- Proportion of respondents expressing needs for key eServices.

The measures can be viewed according to the following dimensions:

- Region.

- Time (at present 2014, 2017-survey results will be used to update results).

- Respondent's age.

- Respondent's gender.

- Respondent's education level.

- Respondent's living area type.

- Respondent's morbidity (chronic illness).

- Respondent's frequency of health service use.

The plan is to get the first database reports on eHealth monitoring published by mid2017. The system is able to present national-level data from Finland, and can host common indicator data also from other Nordic countries (Figure 6). 
Figure 6: Examples of the system for reporting eHealth strategy target area no.1 (citizens as service users) objectives in Finland

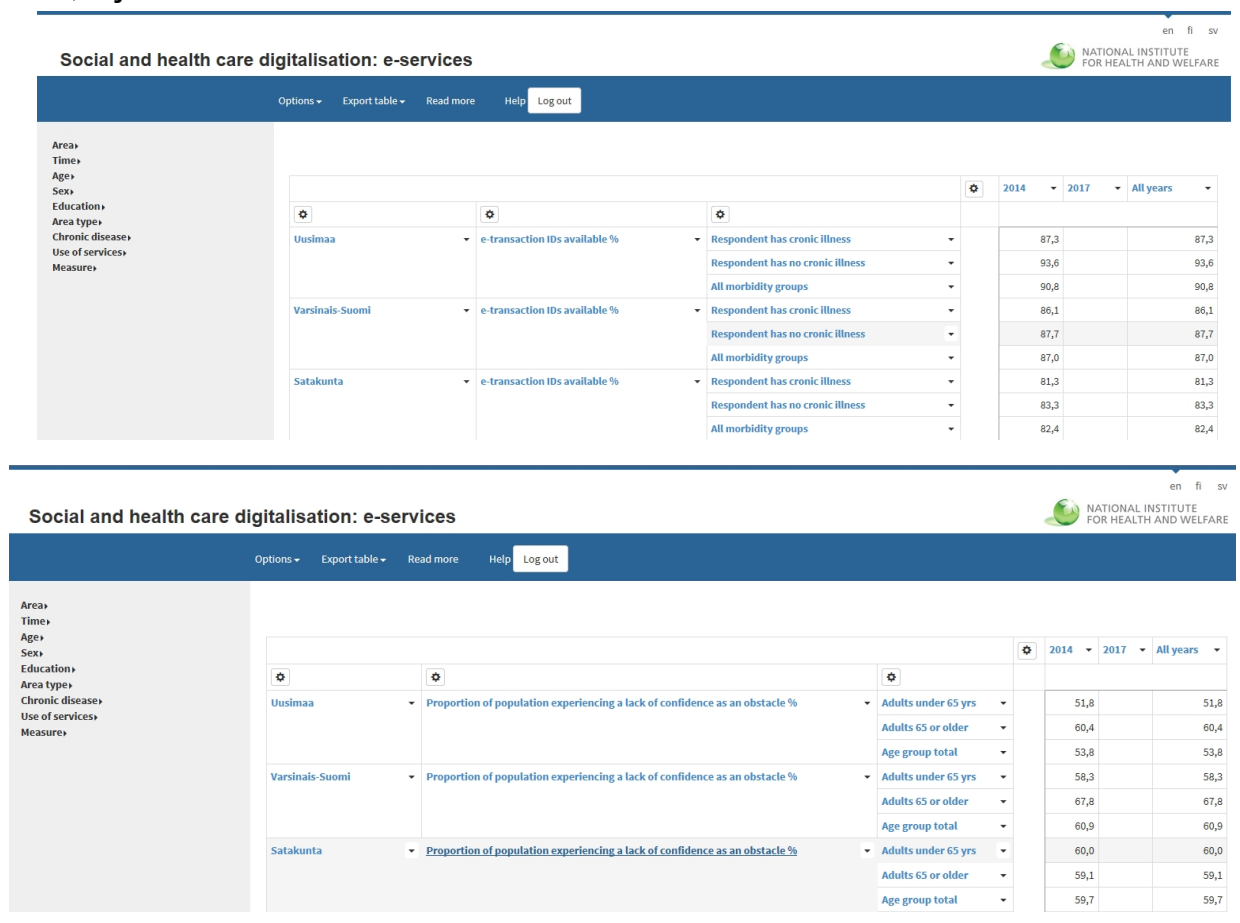

The system allows user to select the measure(s) of interest and the dimensions in which they are to be viewed. It also allows for hiding unnecessary data (e.g. if the user only wants to compare results of their own region with the results from the whole country). The dynamic reporting provides a wealth of data for the user, e.g. the view selected for Figure 6 already gives raise to several conclusions:

- Lack of trust in eHealth services is a relatively big barrier for eService use among respondents.

- On the country-level, respondents aged under 65 experience less lack of trust than those aged over 65 , but the situation is reversed in some regions.

- Some regions seem to have much more overall trust in eServices regardless of age than other regions.

These conclusions (together with the more detailed results on concrete lack-of-trustissues) can be used not only when tailoring measures to support citizens in the use of eHealth services, but also for baseline information, against which the 2017 situation can be reviewed. 


\subsubsection{Sweden}

Reports (e.g. organisational survey) are available on the Inera website https://eHealthstats.inera.se/ and http://www.inera.se/invanartjanster/ eHälsa i landstinget (2015) SLIT-gruppen rapport (4).

Open data is anonymous, with numbers presented as aggregated measures.

Variables used to sample data (Inera):

- No. of visits and services provided

- No. of logins and type of questions asked and type of information searched

- No. of users of biobank register, number of logs, number of accounts etc

- No. and frequency of questions asked

- No. of questions asked through UMO; platform used to access the platform, no. of answered questions.

Variables used to sample data (1177 and eHälsomyndighetens websites)

- Access and Read the EHR. Through the portal, patients can access their EHRs in real time, read e.g. medical notes, diagnoses, and vaccinations. Decision about what kind of information is accessible is taken at regional level and thus the information content varies between regions.

- ePrescription.

- Contact your primary healthcare provider.

- Renew and follow up your medication list.

- $\quad$ Services for individuals with rheumatism.

Patients log in to the portal with the same electronic ID as they use for banking and other government eServices. Yearly reports are produced and some Information is continuously updated.

Variables used to sample data (SLIT report)

- No. of users of different IS; type of systems used.

- Type and no. of eHealth services most frequently used.

- Type of dental system used.

- Percentage of personnel that have received educations about how to handle journal systems.

- IT costs / county council.

\subsubsection{Norway}

In Norway the Directorate for eHealth updates key figures on selected eHealth services monthly at https://ehelse.no/nokkeltall-e-helse (5). The data indicate the number of logins and usage, while individual users cannot be identified. 
helsenorge.no (Web portal for citizens) (6) http://www.helsenorgebeta.net/wpcontent/uploads/2016/08/helsenorge_statistikk_juli2016.pdf publishes the following eHealth indicator data:

- No. of visits to different pages and services provided through the portal. Statistics built on the Google Analytics tool.

- ePrescriptions.

- No. of ePrescriptions sent and delivered.

- No. of unique prescribers who have been using ePrescriptions (last 100 days).

- No. of ePrescriptions prescribed at hospitals.

- No. of logins to "My prescriptions": public citizen service for all Norwegians provided through the "helsenorge.no" portal.

- Kjernejournal (personal patient record).

- No. of certified users.

- No. of visits per week. Can be broken down geographically.

- Health information exchange through the Norwegian health net (https://meldingsteller.nhn.no).

- No. of messages sent. Can be broken down into sender, recipient, type of message and format of message.

- Other specific data on traffic in the health net can be provided upon request.

A Norwegian "eHealth monitor" is under construction. The work is directed by the Norwegian Directorate for eHealth and includes collaborators from research institutions, i.e. the Norwegian Centre for eHealth Research (NSE) and the Health Informatics Research Group at the Norwegian University of Science and Technology. The work is in the early planning phase.

\subsubsection{Denmark}

MedCom reporting

MedCom is a central player within data communication in the Danish Healthcare sector, and was established in 1994 as a publicly funded, non-profit cooperation. MedCom facilitates cooperation between authorities, organizations and private firms linked to the Danish healthcare sector. MedCom is financed and owned by the Ministry of Health, the Danish Regions, and Local Government Denmark.

MedCom has developed standards and profiles regarding the exchange of healthcare-related data throughout the entire Danish healthcare sector. Furthermore, MedCom has service- and technology activities regarding national infrastructure components, including The Danish Healthcare Data Network (SDN), the video hub (VDX) and the national home-monitoring database [http://medcom.dk].The central 
position in the communication of healthcare data allows MedCom to monitor a number of traffic indicators. MedCom variables monitored:

- Messages. The dominant message-based (point-to-point) communications include the following transmitters: hospitals, GPs, practicing specialists, physiotherapists, chiropractors, psychologists, who can transmit the messages indicated in the table. Values for all the variables are published on MedCom.dk every month. Aggregated annual data can be retrieved through MedCom statistics database.

Table 3: MedCom message variables monitored Hospitals GP's Specialist Physio Therapist Chiropractor Psychologist

Discharge letter

Outpatient discharge letter

E\&A discharge letter

Diagnostic image letter

Laboratory test result

Microbiology test result

Pathology test result

Correspondence letter

Prescription

Booking message

Hospital referral

Discharge report

Care plan

Laboratory test order

Pathology test order

Image diagnostic test order

Physician account

Binary document transport

Physiotherapy referral

Physiotherapy discharge letter

Physiotherapy account

Specialist referral

Specialist discharge letter

Chiropractor account

Psychology referral

Psychology discharge letter

Psychologist account

\section{$x$}

$x$

$x$
$x$

$x$
$x$

$x$

$x$

$x$

$x$

$x$

$X$
$X$

$\begin{array}{ll}x & x \\ x & x \\ x & x \\ & \\ x & x \\ x & x \\ x & x \\ x & x \\ x & x\end{array}$


discontinues any form of medication in the record during a day, this will be summed up as one medication consultation. If the GP marks the "Update medication record" function on the patient that same day (multiple updates on a patient the same day will be summed up as one), this will be noted as coinciding. Ideally, the indicator would reach $100 \%$, indicating that all alterations in medication are followed by an assurance from the GP that the shared medication list is up to date. However, the GPs are not obligated to click on the "Update medication record"-button even though they are obliged to ensure that the list is in fact correct. The indicator is available for the total number of patients and for the group of GP patients who have their medication administered by the municipalities (e.g. nursing homes). The indicator does not include data from hospitals or specialists.

- Degree of implementation of the shared medication record in the municipalities. The eHealth systems in the municipality do not interact seamlessly with the shared medication record repository. This means that the municipalities have to retrieve a copy of the shared medication record for every single patient they administer medication to. When the medication record has been retrieved once, the municipal systems will show a warning when there are updates to the patients shared medication record - and then the healthcare personnel in the municipality has to retrieve the updated version. This is done electronically, but has to be initialised. The indicator shows the percentage of retrievals of the shared medication records in relation to the number of patients in which this should have been done. The indicator regarding the degree of implementation of the shared medication record in the municipalities should ideally be $100 \%$.

\section{eRecord}

The eRecord contains a summary of hospital EHR information on each citizen who has been admitted to a hospital. All physicians and specifically authorised health professionals (e.g. nurses authorised by a physician) can access the records of patients with whom they have a professional relationship - diagnostic or treatment. Patients can access their own record. MedCom publish statistics on:

- No. of users broken down into hospitals, practitioners (GPs and Specialists), and citizens.

- No. of records, processes and events in the database.

- No. of lookups across the former county borders.

An example of monitoring data is shown in figure below.

\section{KIH database statistics}

This database was developed to store data from home monitoring to create a common national infrastructure for home monitoring. Three main umbrella projects are included in the statistics (KIH-project, Capital Region and Central Denmark Region, as well as 
TeleCare Nord in the North Denmark Region). The projects store their data in the database, and the monitoring concerns traffic to the database:

- No. of patients reported per month.

- No. of measurements per month.

Figure 7: Example of MedCom monitoring data: number of look-ups by hospitals and citizens from 2007 to 1st quarter of 2016

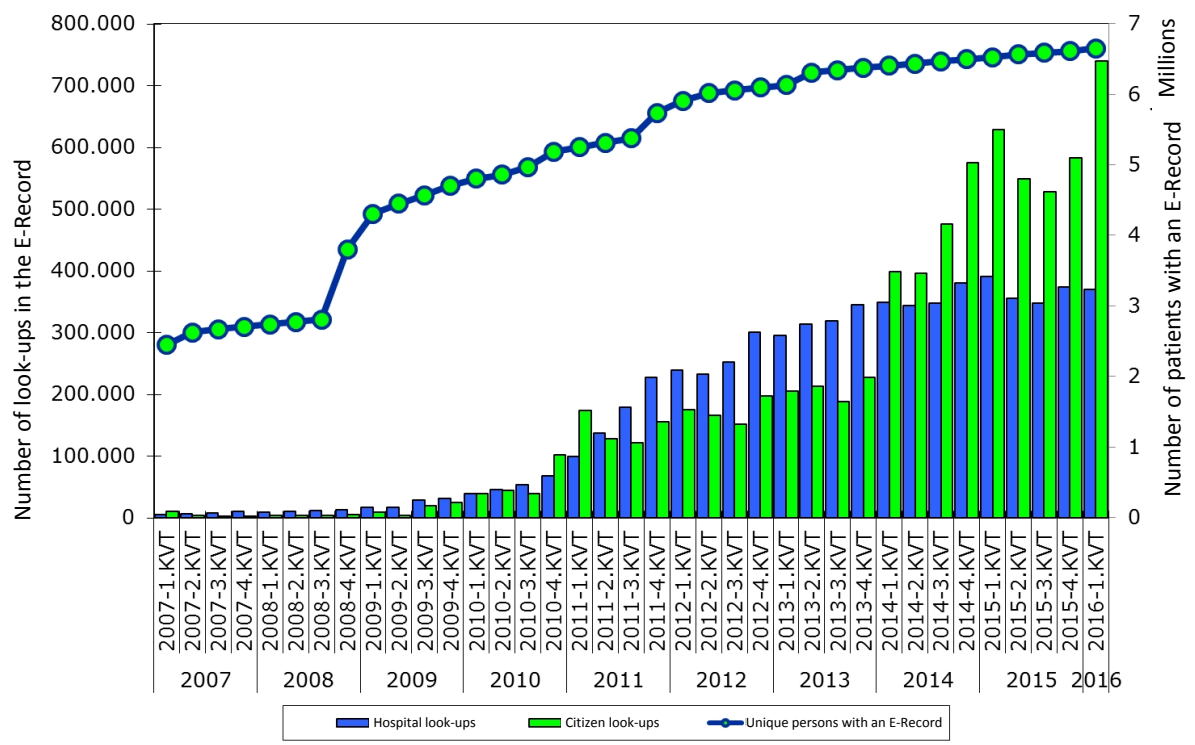

Web Patient

Web Patient is a system that enables GPs to request and receive information from home monitored measurements for use in their daily digitized work procedures. The following measurements can be requested:

- Blood Pressure.

- Anxiety-, stress-, and depression scorings.

- Danish Prostate Symptoms Scorings (DAN-PSS).

- Blood glucose profile.

- Weight control.

- Liquid intake and flow of urine.

- Peak flow.

Examples of the monitoring can be seen in figure below. 
Figure 8: Number of requested information schemes on WebPatients from GPs per month in 2016

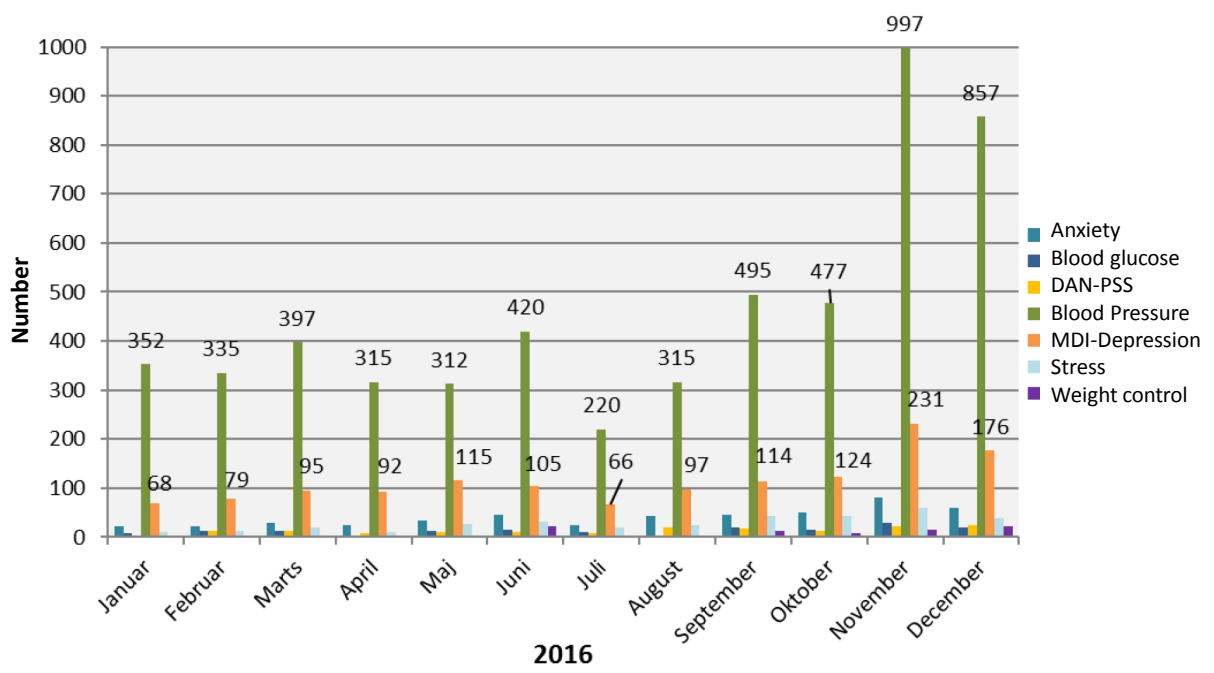

Telemedicine

A few telemedicine projects have specific statistics on usage monitored and published by MedCom:

- Tele-dermatology - transferral of (EDI)standardized letters from GPs to specialists.

- Telemedical treatment of ulcer - transmission of photos of ulcers from patients' home to hospitals.

\subsubsection{Iceland}

In Iceland the Directorate for Health monitors some key data on the usage of eHealth services on a monthly basis. Those include the following:

- No. of ePrescriptions on a national level.

- No. of health professionals' logins to interconnected (real time sharing of) health records. Number of logins to secure messaging between health professionals and their patients.

- No. of logins by citizens to access the national citizen health portal.

- No. of logins by citizens to view their ePrescriptions using the national citizen health portal.

- No. of ePrescription renewal requests by citizens using the national citizen health portal.

- No. bookings by citizens using the national citizen health portal.

- No. of logins by citizens to view their immunization data. 
- No. of citizens (unique ID) accessing the national citizen health portal.

Currently, the data are not openly available, but there are plans to make this information available by spring 2017 and updated monthly on the Directorate for Health web page. However, if someone wants to access the data, they can apply for it from the Directorate for Health. The survey data on common Nordic eHealth indicators has been published in "Talnabrunnur" (7), which is the channel the Directorate for Health uses to publish statistics on a monthly basis.

\subsection{International online reporting systems}

In addition to the national reporting systems, two international online reporting systems were reviewed as part of this task: The NOMESCO database (nowbase.org) and the Eurostat database.

\subsubsection{NOWBASE database}

NOWBASE is a shared website for the Nordic Medico-Statistical Committee (NOMESCO) and the Nordic Social Statistical Committee (NOSOSCO). These two committees under the Nordic Council of Ministers are:

- Working to ensure that health and social statistics in the Nordic Countries are comparable between countries.

- Gathering statistics within this field.

- Presenting these statistics and making them widely available.

National delegations have been appointed to the Nordic Medico-statistical Committee (NOMESCO). The delegations are gathered yearly at the Plenary Meeting, which decides on coming activities. As a part of the work, NOMESCO and NOSOSCO carry out specific projects with the aim of developing and furthering the statistical description of Health and Social Protection. These projects may come about on their own initiative, or they may be specific requests from the Nordic Council of Ministers. Usually the projects produce a report, and many publications came about in this way. In addition, they frequently result in new or revised tables in the regular publications Social Protection and Health Statistics. Current projects are:

- Sickness Absence in the Nordic Countries.

- Social Inequalities in Causes of Death.

- Microsimulation Models in the Nordic Countries.

- Welfare Indicators. 
According to the Head of Delegation, Chair of NOMESCO Mika Gissler, the organisations responsible for data collection need to make a contract with NOMESCO to deliver key results when they have been collected. The NOMESCO interest in eHealth indicator data was discussed in the NOMESCO meeting in Vejle on 1-2.9.2016. A response from the meeting to the NeRN group was: When the following information is provided, the proposal will be handled in the plenary meeting for decision-making:

- A precise listing of proposed indicators.

- Names of organisations who are responsible for data collection (and be making the contract with NOMESCO.)

- Information on how the data will be collected, reported.

- Information on who will cover the costs.

This response was discussed in the NeRN meeting in Reykjavik on 8-9.9.2016, considering it in light of the information collected on eHealth monitoring governance systems. It was considered that the first condition is still pending, until an updated analysis of eHealth policies and their priorities leading to an updated list of eHealth indicators is reported. The second condition cannot be met, since the decisions had not been made in all the Nordic countries on responsible organisations. The third condition depends on the first condition. The fourth condition could also not be met, due to undeveloped eHealth monitoring governance systems.

Agreements on the details of the governance of eHealth monitoring work thus pose a major obstacle at present to offer eHealth indicator data to NOMESCO. The NeRN participants stated that a clear mandate for data collection and resources from the Ministry in the respective countries is needed in order to make a contract with NOMESCO. This conclusion leads back to the question of the specifying and funding of the eHealth monitoring governance system in each of the Nordic countries.

\subsubsection{Eurostat}

Eurostat is the statistical office of the European Union situated in Luxembourg. Its mission is to provide high quality statistics for Europe at a European level that enable comparisons between countries and regions. It supplies statistics to other DGs and supplies the Commission and other European Institutions with data so they can define, implement and analyse Community policies. Eurostat is part of the portfolio of Marianne Thyssen, the Commissioner for Employment, Social Affairs, Skills and Labour Mobility.

The Eurostat database (http://ec.europa.eu/eurostat/data/database) contains the full range of data publicly available at Eurostat. Eurostat survey data collection is based on national surveys that follow the Eurostat model survey, which ensures a high level of comparability. Compliance with the Eurostat definitions and recommendations is verified through methodological reports, following a harmonised reporting template defined by Eurostat. The results are presented in multi-dimensional tables with various 
selection features and export formats. As a framework regulation, it allows for adjustment to newly evolving needs by users and decision-makers through annually implementing measures.

Eurostat Information Society Statistics track the usage of Information and Communications Technologies (ICT). More specifically, statistics on the information society are monitoring three aspects:

- The completion of a single European information space.

- Innovation and investment in ICT research.

- Achieving an inclusive European information society.

These aspects correspond with the main aims of i2010 - a European Information Society for growth and employment. This is a strategic framework for the information society and a key element of the renewed Lisbon Strategy, and it offers a comprehensive strategy for the ICT and media sector. The collection of the data on the information society corresponds to the framework Regulation (EC) no. 808/2004, which ensures that the data are harmonised. The regulation contains two modules, covering:

- Enterprises.

- Households and individuals.

Eurostat's information society indicators focus on households, individuals and enterprises. There is one eGovernment indicator, and none on the healthcare sector. The Eurostat information society indicators thus lack sector-specific indicators. The section on healthcare indicators contains one possible topic - healthcare resources, under which eHealth availability and usage-indicators could fit. Current resourceindicators focus on the number of beds and facilities and medical technologies.

Currently, the Nordic indicators do not fulfil the requirements set out in the metadata section of the Eurostat indicators in regard to, for example, reference area, classification system, institutional mandates, frequency of dissemination, accessibility of documentation, completeness, and accuracy. 


\subsection{Conclusions}

Analysis of the contents of online reporting systems show that at present:

- Quite a lot of data are already available online on reporting usage of eHealth services and functionalities in the Nordic countries, though the contents of the data vary.

- There are multiple reporting systems containing eHealth monitoring data. To our knowledge, the eHealth reporting systems in Finland and Iceland are currently most clearly linked to the eHealth strategy objectives in a manner that makes it easy to follow the attainment of specific the policy goals.

- The data reported online reflect the differences in the eHealth systems: e.g. in Denmark, no. of point-to-point messages is being counted at the national level, but more complex legislation-based indicators related to shared medication record have also been developed (e.g. \% of updates of medical record in relation to alterations in medication per patient).

- All the Nordic countries are using a shared medication record. The variables for automatic monitoring of usage of the shared data and dimensions in which to view it are still poorly defined and not harmonious, requiring common specification work with the institutions responsible for the logs.

The eHealth group has been promoting systematic statistical reporting of Nordic eHealth maturity, which brings eHealth monitoring and benchmarking a step closer to becoming part of the Nordic countries statistical knowledge-base. The provision of systematic statistical data requires a clear mandate for an organisation to collect the statistics as well as having the resources to do so. This work also requires detailed knowledge not only of eHealth strategies but also of eHealth legislation as basis of indicator generation.

At present, a lack of clear governance for eHealth monitoring in the Nordic countries is a major obstacle preventing the provision of common indicator data to NOWBASE: To a large degree, the responsible organisations have not been selected, mandated and resources allocated to take care of the task. (See Chapter on governance of eHealth monitoring.) The NeRN work towards common indicator data on Functionalities (based on OECD work) is a first step towards common reporting. However, without a clear governance of eHealth indicator work in the Nordic countries there is a real threat that common eHealth indicator data will remain divergent in the Nordic countries and not publicly available in common formats via statistical databases. This needs to be recognized in the Nordic and country-level eHealth governance, with relevant resources reserved. 


\subsection{References}

(1) AvoHILMO (Register of Primary Healthcare Visits)(2017):

https://www2.thl.fi/avohilmo_report/report?id=basic\&l=fi\&year=2016\&palveluntuottaja=\&am matti $=\&$ palvelumuoto $=$ \&yhteystapa $=9400$

(2) AvoHILMO online report (2017):

https://sampo.thl.fi/pivot/prod/fi/avo/peruso1/fact_ahil_peruso1?row=alue$11810 \&$ row=yhteystavat $87782 \&$ column=aika- $87596 \&$ filter=measure- 94748

(3) The THL dynamic reporting system (2016): https://www.thl.fi/fi/web/tiedonhallinta-sosiaalija-terveysalalla/mita-tiedonhallinta-on-/sosiaali-ja-terveydenhuollontietojarjestelmapalveluiden-seuranta/digitalisaatiota-kuvaavat-indikaattorit

(4) SLIT-gruppen rapport (2015):

http://www.inera.se/Documents/OM_OSS/Styrdokument_o_rapporter/SLITrapporter/eHlsa_i_landstingen_SLIT_2015.pdf

(5) Nøkkeltall e-helse: https://ehelse.no/nokkeltall-e-helse

(6) helsenorge.no: http://www.helsenorgebeta.net/wpcontent/uploads/2016/08/helsenorge_statistikk_juli2016.pdf

(7) Talnabrunnur (2015):

http://www.landlaeknir.is/servlet/file/store93/item26039/Talnabrunnur_jan\%C3\%BAar_2015.pdf 


\section{Common indicators for eHealth services: patients' and citizens' points of view}

This chapter depicts results of the second task set to the NeRN network that included: 1) eHealth indicators to measure patients' and citizens' points of view in the Nordic countries, 2) comparison of the results of existing measurements and a suggestion of common indicators for future measurements of patients' and citizens' points of view regarding eHealth use and expectations.

\subsection{Methods}

The following materials/data and methods have been used in order to produce this report. Materials included the following Nordic eHealth citizen survey questionnaires:

- Denmark, 2013 (in Danish) (1).

- Finland, 2013 (in Swedish) (2).

- Norway, 2007 (in Norwegian) (3).

- Norway, 2013 (in Norwegian) (4).

- Sweden, National Patient Survey, 2013 (5).

- Sweden, Care Barometer, 2013 (6).

The analysis of the surveys was performed as follows:

- A content analysis of the surveys was performed to provide a list of variables used to measure output in the different national surveys.

- The surveys were compared with each other to identify common variables.

- Only questions that were asked by at least two countries were included in the list of variables presented in this report.

- Further variables of relevance to capture innovativeness, renewal and progression in the use and re-use of services for the eHealth area were added to the list of common variables. The new variables were taken from experiences sampled and reported in current research projects in Sweden.

- A preliminary report was sent to the working group with the aim of validating the results and achieving consistency and legitimacy in the results. 


\subsection{Results}

\subsubsection{The citizen survey indicators and measures}

\section{Common background variables}

The background variables that were common within all the citizen surveys included age, gender, and educational level. The list of variables measured by surveys targeted at patients and citizens are presented in Table 4. Although these indicators were common for all the countries, some minor variations were identified. Regarding questions on "age", all the countries, except Norway, asked for the year of birth. Norway asked for the age in years. All the countries had (male/female) gender questions. No country had more than two response values. Regarding questions on "education", the possible values listed were similar but not exactly the same in the different countries and response scales varied (Table 4 ).

Table 4: Comparability of key background variables between the Nordic surveys targeting patients and citizens. NPE=Nationell patientenkät (5); VB=Vårdbarometer (6)

Variable Country Question Answer

\begin{tabular}{|c|c|c|c|}
\hline \multicolumn{4}{|l|}{ Age } \\
\hline Age & D & Which year were you born? & year \\
\hline Age & $\mathrm{F}$ & Year of birth 19_ & year \\
\hline Age & $\mathrm{N}$ & How old are you? & age \\
\hline Age & $\mathrm{S}$ & Which year were you born? & år \\
\hline \multicolumn{4}{|l|}{ Gender } \\
\hline Gender & D & Gender & woman, man \\
\hline Gender & $\mathrm{F}$ & Gender & man, woman \\
\hline Gender & $\mathrm{N}$ & Gender & man, woman \\
\hline Gender & $\mathrm{S}$ & Are you man or woman? & man, woman \\
\hline \multicolumn{4}{|l|}{ Education } \\
\hline Education & D & $\begin{array}{l}\text { Which is the highest education you } \\
\text { have performed? }\end{array}$ & $\begin{array}{l}\text { Elementary school; Secondary school; High school; } \\
\text { Vocational education; Short higher education (below } \\
3 \text { years); Longer higher education (3-4 years); Long } \\
\text { higher education (over } 4 \text { years); Don't know }\end{array}$ \\
\hline Education & $\mathrm{F}$ & $\begin{array}{l}\text { Which is the highest educational } \\
\text { exam you have achieved? }\end{array}$ & $\begin{array}{l}\text { Elementary school exam; Basic vocational exam; High } \\
\text { school exam; Bachelor; Master; PhD }\end{array}$ \\
\hline Education & $\mathrm{N}$ & $\begin{array}{l}\text { Which is the highest education you } \\
\text { have performed? }\end{array}$ & $\begin{array}{l}\text { Pre-school, no education; Elementary school; } \\
\text { Secondary school; Upper secondary school; High } \\
\text { school (general); High school (vocational); Vocational } \\
\text { education; University candidate (1-3 years); University } \\
\text { master (4-5 years); Research education; Don't want to } \\
\text { answer; Don't know }\end{array}$ \\
\hline Education & $\mathrm{S}$ & $\begin{array}{l}\text { Which is the highest education you } \\
\text { have finished? }\end{array}$ & Elementary school; High school; University; Other \\
\hline
\end{tabular}


Non-comparable background variables

Apart from the common variables, Norway also asked for the type of profession the individual has attained. However, professional level is strongly correlated with educational level and for this reason, it can be neglected. It is also important to note that both Finland and Norway asked for work status, and that Sweden asked for the country of birth and whether the mother tongue was Swedish or not.

Questions regarding work and living situation are asked in several countries but answers are not comparable due to the variation in questions asked in the different countries (table 5).

Table 5: Non-comparable background variables. NPE=Nationell patientenkät (5); VB=Vårdbarometer (6)

Variable Country Question Answer

Family situation

Family situation

Family situation

Family situation

Family situation

Family situation

Family situation

$S$ (NPE)

$S(V B)$
Are there any children under the age of 16 living in your home?

Do you have custody for someone who is:

How many children under the age of 18 live in your household

What does your family situation look like - are you:

How do you live?

Living situation

Living situation

Living situation

Living situation

Living situation

Living situation

Home town

Home town

Home town

Home town

N (-07)

Where do you live? yes; no

under 18; elderly

number of children

Single without children living at home; Single with children living at home; Married/in partnership without children living at home; Married/in partnership withchildren living at home; Living with parents; Aother family situation

Own or rented home; Service home, Rehabilitation home or Elderly care home; Somewhere else, i.e.:

post code

Type of living location: City; urban area; sparsly populated area

Big city; Town; Urban area (more than 200 inhabitants); sparsly populated area (sless than 200 inhabitants); Don't know/not answered 
Common health variables in the citizen surveys

Common variables regarding the individual health of the respondents included: current state of health and existence of chronic (or long-term) disease. Regarding "current state of health", all countries used a 5-point Likert scale, making the values comparable between countries. However, Denmark and Norway (year 2007 questionnaire) also included the alternative "don't know" as a possible answer which the other countries did not. The question about existing health problems was posed a bit differently in the different countries. Whereas Denmark and Finland asked for chronic disease, Norway and Sweden asked for long-term disease or health problems. Denmark and Finland further differentiated between physical or psychological diseases, while Norway and Sweden did not. Norway also asked for long-term diseases of relatives as this might have implications for one's own health. 
Table 6: Comparability of common health variables between the Nordic surveys targeting patients and citizens; NPE=Nationell patientenkät (5); VB=Vårdbarometer (6)

\begin{tabular}{|c|c|c|c|}
\hline Variable & Country & Question & Answer \\
\hline \multicolumn{4}{|l|}{ Current state of health } \\
\hline Current state of health & $\mathrm{D}$ & $\begin{array}{l}\text { How would you judge your general state of } \\
\text { health? }\end{array}$ & $\begin{array}{l}\text { Very good; Good; Neither good } \\
\text { or bad; Bad; Very bad; Don't } \\
\text { know }\end{array}$ \\
\hline Current state of health & $\mathrm{F}$ & Do you think your current state of health is: & $\begin{array}{l}\text { Very good; Good; Neither good } \\
\text { or bad; Bad; Very bad; }\end{array}$ \\
\hline Current state of health & $N(-07)$ & $\begin{array}{l}\text { In general, how would you judge your state } \\
\text { of health? }\end{array}$ & $\begin{array}{l}\text { Very good; Good; Neither good } \\
\text { or bad; Bad; Very bad; Don't } \\
\text { want to answer; Don't know }\end{array}$ \\
\hline Current state of health & $N(-13)$ & $\begin{array}{l}\text { How is your health in general? Would you } \\
\text { say it is: }\end{array}$ & $\begin{array}{l}\text { Very good; Good; Neither good } \\
\text { or bad; Bad; Very bad; Don't } \\
\text { want to answer/Don't know }\end{array}$ \\
\hline Current state of health & S (NPE) & $\begin{array}{l}\text { How would you judge your general state of } \\
\text { health? }\end{array}$ & $\begin{array}{l}\text { Excellent; Very good; Good; Ok; } \\
\text { Bad }\end{array}$ \\
\hline Current state of health & $S(V B)$ & $\begin{array}{l}\text { How would you judge your general state of } \\
\text { health? }\end{array}$ & $\begin{array}{l}\text { Very good; Good; Neither good } \\
\text { or bad; Bad; Very bad; }\end{array}$ \\
\hline \multicolumn{4}{|l|}{$\begin{array}{l}\text { Long-term/chronic } \\
\text { disease }\end{array}$} \\
\hline $\begin{array}{l}\text { Long-term/chronic } \\
\text { disease }\end{array}$ & D & Do you have one or more chronic diseases? & $\begin{array}{l}\text { Yes - physical; Yes - } \\
\text { psycological; No; Don't know; } \\
\text { Don't want to answer }\end{array}$ \\
\hline $\begin{array}{l}\text { Long-term/chronic } \\
\text { disease }\end{array}$ & $\mathrm{F}$ & $\begin{array}{l}\text { Do you have one or more diagnosed chronic } \\
\text { diseases? You can choose more than one } \\
\text { alternative. }\end{array}$ & $\begin{array}{l}\text { Yes - physical; Yes - } \\
\text { psycological; No; Don't know }\end{array}$ \\
\hline $\begin{array}{l}\text { Long-term/chronic } \\
\text { disease }\end{array}$ & $N(-07)$ & $\begin{array}{l}\text { Do you or a relative suffer from a long-term } \\
\text { disease? }\end{array}$ & $\begin{array}{l}\text { Yes - myself; Yes - a relative; No; } \\
\text { Don't want to answer; Don't } \\
\text { know }\end{array}$ \\
\hline $\begin{array}{l}\text { Long-term/chronic } \\
\text { disease }\end{array}$ & $N(-13)$ & $\begin{array}{l}\text { Do you or a relative suffer from a long-term } \\
\text { disease? }\end{array}$ & Yes - myself; Yes - a relative; No \\
\hline $\begin{array}{l}\text { Long-term/chronic } \\
\text { disease }\end{array}$ & $\mathrm{S}(\mathrm{NPE})$ & & \\
\hline $\begin{array}{l}\text { Long-term/chronic } \\
\text { disease }\end{array}$ & $S(V B)$ & $\begin{array}{l}\text { Do you have a long-term disease, problems } \\
\text { after an accident, decreased functional } \\
\text { capability or any other long-term health } \\
\text { problem? }\end{array}$ & Yes; No; Don't want to answer \\
\hline
\end{tabular}

Non-comparable health variables

In Finland and Sweden questions regarding lifestyle were included in the surveys. However, questions were posed in different ways. Whereas the Finnish questionnaire asked about the amount of physical activity and a healthy diet, the Swedish questionnaire asked about patients' attitudes towards discussing lifestyle with their physician or other healthcare providers. 
Common eHealth variables in the citizen surveys

The analysis of the surveys showed that common eHealth variables in the different questionnaires included the following categories: a) internet use, b) use of eHealth services (and underlying sub-categories), c) perception of eHealth services and d) future requirements/wishes. The following sections and tables describe in more detail what has been measured in the different Nordic countries, and where applicable, the common variables are presented:

- a) Internet use

Questions regarding internet use were related either to the purpose or the frequency of internet use. Questions about internet use were dependent on the availability of eServices for the intended purpose. In Sweden, patient eServices were introduced later than in the other Nordic countries and as such internet-userelated questions were largely lacking.

In contrast, Denmark, Finland and Norway all asked about internet use for the following purposes:

- Healthcare consultation.

- Ordering of medication or health-related certificates.

- Appointment booking.

- Search for health-related information.

- Lifestyle management.

Both Denmark and Norway also asked whether patients had used social media to communicate with their peers and Norway asked about the use of online treatment. Response options were framed as either multiple choice checkboxes or yes/no/don't know responses. Norway also asked about the frequency of Internet use for the different purposes.

- b) Use of eHealth services

Questions regarding the use of eHealth services were usually not comparable, with the exception of the question on whether certain (country specific) eHealth services had been used and how often. These questions are becoming obsolete and are being replaced by log data. However, Denmark, Norway and Finland asked about communication with healthcare through the Internet. Denmark also asked for reasons why not to do so. All countries asked citizens about their possibilities for accessing their medical records. Finland and Sweden also asked about the use of self-care management tools and risk tests. We also see the appearance of questions about proxy use of eHealth services and the importance of having eHealth services available in foreign languages. 
- c) Perception of eHealth services

Questions regarding the perception of eHealth services were similar in Denmark, Finland and Norway, falling under the following sub-categories: Physical contact, IT use, Transparency, Collaboration, Trust, Security, Patient safety and Privacy (table 7). Data from Denmark and Finland were comparable as both applied a 5point Likert scale.

Table 7: Perception of eHealth services questions, responses and variables used in the different countries

\begin{tabular}{|c|c|c|c|}
\hline Variable & Country & Question & Answer \\
\hline $\begin{array}{l}\text { Perception of } \\
\text { eHealth } \\
\text { Services }\end{array}$ & & & \\
\hline Physical & & & \\
\hline $\begin{array}{l}\text { Contact } \\
\text { Perception of } \\
\text { eHealth } \\
\text { Services }\end{array}$ & D & $\begin{array}{l}\text { I feel that my treatment is insufficient } \\
\text { if I cannot have a physical contact or } \\
\text { consultation. }\end{array}$ & $\begin{array}{l}\text { Completely agree, Mostly agree, Neither } \\
\text { agree nor disagree, Mostly disagree, } \\
\text { Completely disagree, Don't know }\end{array}$ \\
\hline $\begin{array}{l}\text { Perception of } \\
\text { eHealth } \\
\text { Services }\end{array}$ & $\mathrm{F}$ & $\begin{array}{l}\text { I don't think I receive adequate care if I } \\
\text { do not meet a physician face-to-face. }\end{array}$ & $\begin{array}{l}1=\text { Completely disagree, } 2,3,4,5=\text { Completely } \\
\text { agree }\end{array}$ \\
\hline $\begin{array}{l}\text { Perception of } \\
\text { eHealth } \\
\text { Services }\end{array}$ & $D$ & $\begin{array}{l}\text { I prefer to have a face-to-face } \\
\text { dialogue. }\end{array}$ & $\begin{array}{l}\text { Completely agree, Mostly agree, Neither } \\
\text { agree nor disagree, Mostly disagree, } \\
\text { Completely disagree, Don't know }\end{array}$ \\
\hline $\begin{array}{l}\text { Perception of } \\
\text { eHealth } \\
\text { Services }\end{array}$ & $\mathrm{N}$ & I prefer to meet face-to-face. & $\begin{array}{l}\text { Completely disagree }=1 \text { to Completely agree }= \\
\text { 4. Don't know }=5 \text {. }\end{array}$ \\
\hline $\begin{array}{l}\text { Perception of } \\
\text { eHealth } \\
\text { Services }\end{array}$ & $D$ & $\begin{array}{l}\text { The personal meeting cannot be } \\
\text { replaced by an email conversation. }\end{array}$ & $\begin{array}{l}\text { Completely agree, Mostly agree, Neither } \\
\text { agree nor disagree, Mostly disagree, } \\
\text { Completely disagree, Don't know }\end{array}$ \\
\hline $\begin{array}{l}\text { Perception of } \\
\text { eHealth } \\
\text { Services }\end{array}$ & $\mathrm{F}$ & $\begin{array}{l}\text { Personal meetings cannot be replaced } \\
\text { by electronic contacts. }\end{array}$ & $\begin{array}{l}1=\text { Completely disagree, } 2,3,4,5=\text { Completely } \\
\text { agree }\end{array}$ \\
\hline $\begin{array}{l}\text { Perception of } \\
\text { eHealth } \\
\text { Services }\end{array}$ & D & $\begin{array}{l}\text { It is important to me not needing to } \\
\text { meet physically at my caregiver. }\end{array}$ & $\begin{array}{l}\text { Completely agree, Mostly agree, Neither } \\
\text { agree nor disagree, Mostly disagree, } \\
\text { Completely disagree, Don't know }\end{array}$ \\
\hline $\begin{array}{l}\text { Perception of } \\
\text { eHealth } \\
\text { Services }\end{array}$ & $D$ & $\begin{array}{l}\text { I save time and do not want to meet at } \\
\text { my caregiver. }\end{array}$ & $\begin{array}{l}\text { Completely agree, Mostly agree, Neither } \\
\text { agree nor disagree, Mostly disagree, } \\
\text { Completely disagree, Don't know }\end{array}$ \\
\hline $\begin{array}{l}\text { Perception of } \\
\text { eHealth } \\
\text { Services }\end{array}$ & D & $\begin{array}{l}\text { Non-medical aspects of my care are } \\
\text { overseen without a face-to-face } \\
\text { meeting with my caregiver. }\end{array}$ & $\begin{array}{l}\text { Completely agree, Mostly agree, Neither } \\
\text { agree nor disagree, Mostly disagree, } \\
\text { Completely disagree, Don't know }\end{array}$ \\
\hline $\begin{array}{l}\text { Perception of } \\
\text { eHealth } \\
\text { Services }\end{array}$ & $\mathrm{F}$ & $\begin{array}{l}\text { Non-medical aspects of my care do } \\
\text { not receive enough attention if I do } \\
\text { not meet a caregiver face-to-face. }\end{array}$ & $\begin{array}{l}1=\text { Completely disagree, } 2,3,4,5=\text { Completely } \\
\text { agree }\end{array}$ \\
\hline $\begin{array}{l}\text { Perception of } \\
\text { eHealth } \\
\text { Services }\end{array}$ & $\mathrm{N}$ & $\begin{array}{l}\text { I wish to communicate more with the } \\
\text { physcian through Internet, email or } \\
\text { eHealth services. }\end{array}$ & $\begin{array}{l}\text { Completely disagree }=1 \text { to Completely agree }= \\
\text { 4. Don't know }=5 \text {. }\end{array}$ \\
\hline $\begin{array}{l}\text { Perception of } \\
\text { eHealth } \\
\text { Services }\end{array}$ & $\mathrm{N}$ & $\begin{array}{l}\text { I wish to communicate more with the } \\
\text { hospital through Internet, email or } \\
\text { eHealth services. }\end{array}$ & $\begin{array}{l}\text { Completely disagree }=1 \text { to Completely agree }= \\
\text { 4. Don't know }=5 \text {. }\end{array}$ \\
\hline
\end{tabular}




\begin{tabular}{|c|c|c|c|}
\hline Variable & Country & Question & Answer \\
\hline $\begin{array}{l}\text { IT Use } \\
\text { Perception of } \\
\text { eHealth } \\
\text { Services }\end{array}$ & $\mathrm{D}$ & I have difficulties to navigate IT. & $\begin{array}{l}\text { Completely agree, Mostly agree, Neither } \\
\text { agree nor disagree, Mostly disagree, } \\
\text { Completely disagree, Don't know }\end{array}$ \\
\hline $\begin{array}{l}\text { Perception of } \\
\text { eHealth } \\
\text { Services }\end{array}$ & $\mathrm{F}$ & $\begin{array}{l}\text { The service I need is not available } \\
\text { electronically. }\end{array}$ & $\begin{array}{l}1=\text { Completely disagree, } 2,3,4,5=\text { Completely } \\
\text { agree }\end{array}$ \\
\hline $\begin{array}{l}\text { Perception of } \\
\text { eHealth } \\
\text { Services }\end{array}$ & $\mathrm{F}$ & $\begin{array}{l}\text { I don't have a computer and Internet } \\
\text { access. }\end{array}$ & $\begin{array}{l}1=\text { Completely disagree, } 2,3,4,5=\text { Completely } \\
\text { agree }\end{array}$ \\
\hline $\begin{array}{l}\text { Perception of } \\
\text { eHealth } \\
\text { Services }\end{array}$ & $\mathrm{F}$ & $\begin{array}{l}\text { I don't have enough computer } \\
\text { knowledge to use electronic services. }\end{array}$ & $\begin{array}{l}1=\text { Completely disagree, } 2,3,4,5=\text { Completely } \\
\text { agree }\end{array}$ \\
\hline $\begin{array}{l}\text { Perception of } \\
\text { eHealth } \\
\text { Services }\end{array}$ & $\mathrm{F}$ & $\begin{array}{l}\text { I don't have interest in using electronic } \\
\text { services. }\end{array}$ & $\begin{array}{l}1=\text { Completely disagree, } 2,3,4,5=\text { Completely } \\
\text { agree }\end{array}$ \\
\hline $\begin{array}{l}\text { Perception of } \\
\text { eHealth } \\
\text { Services }\end{array}$ & $\mathrm{F}$ & It is difficult to find electronic services. & $\begin{array}{l}1=\text { Completely disagree, } 2,3,4,5=\text { Completely } \\
\text { agree }\end{array}$ \\
\hline $\begin{array}{l}\text { Perception of } \\
\text { eHealth } \\
\text { Services }\end{array}$ & $\mathrm{F}$ & $\begin{array}{l}\text { Electronic services are not available for } \\
\text { blind people. }\end{array}$ & $\begin{array}{l}1=\text { Completely disagree, } 2,3,4,5=\text { Completely } \\
\text { agree }\end{array}$ \\
\hline $\begin{array}{l}\text { Perception of } \\
\text { eHealth } \\
\text { Services }\end{array}$ & $\mathrm{F}$ & $\begin{array}{l}\text { The electronic service does not exist in } \\
\text { my mother tongue. }\end{array}$ & $\begin{array}{l}1=\text { Completely disagree, } 2,3,4,5=\text { Completely } \\
\text { agree }\end{array}$ \\
\hline $\begin{array}{l}\text { Perception of } \\
\text { eHealth } \\
\text { Services }\end{array}$ & $\mathrm{F}$ & $\begin{array}{l}\text { The electronic service is difficult to } \\
\text { use. }\end{array}$ & $\begin{array}{l}1=\text { Completely disagree, } 2,3,4,5=\text { Completely } \\
\text { agree }\end{array}$ \\
\hline $\begin{array}{l}\text { Perception of } \\
\text { eHealth } \\
\text { Services }\end{array}$ & $\mathrm{F}$ & $\begin{array}{l}\text { I cannot act proxy for somebody else } \\
\text { using the electronic services even if it } \\
\text { would be necessary. }\end{array}$ & $\begin{array}{l}1=\text { Completely disagree, } 2,3,4,5=\text { Completely } \\
\text { agree }\end{array}$ \\
\hline $\begin{array}{l}\text { Perception of } \\
\text { eHealth } \\
\text { Services }\end{array}$ & $\mathrm{F}$ & $\begin{array}{l}\text { I don't have any use of electronic } \\
\text { services. }\end{array}$ & $\begin{array}{l}1=\text { Completely disagree, } 2,3,4,5=\text { Completely } \\
\text { agree }\end{array}$ \\
\hline $\begin{array}{l}\text { Perception of } \\
\text { eHealth } \\
\text { Services }\end{array}$ & $\mathrm{F}$ & $\begin{array}{l}\text { Elektronic services slow down the } \\
\text { process of reaching health and social } \\
\text { care services. }\end{array}$ & $\begin{array}{l}1=\text { Completely disagree, } 2,3,4,5=\text { Completely } \\
\text { agree }\end{array}$ \\
\hline $\begin{array}{l}\text { Perception of } \\
\text { eHealth } \\
\text { Services }\end{array}$ & $\mathrm{D}$ & $\begin{array}{l}\text { I don't learn anything new from health } \\
\text { IT. }\end{array}$ & $\begin{array}{l}\text { Completely agree, Mostly agree, Neither } \\
\text { agree nor disagree, Mostly disagree, } \\
\text { Completely disagree, Don't know }\end{array}$ \\
\hline $\begin{array}{l}\text { Perception of } \\
\text { eHealth } \\
\text { Services }\end{array}$ & $\mathrm{F}$ & $\begin{array}{l}\text { Terms of use for ehealth services are } \\
\text { long and difficult to understand. }\end{array}$ & $\begin{array}{l}1=\text { Completely disagree, } 2,3,4,5=\text { Completely } \\
\text { agree }\end{array}$ \\
\hline $\begin{array}{l}\text { Perception of } \\
\text { eHealth } \\
\text { Services }\end{array}$ & $\mathrm{D}$ & $\begin{array}{l}\text { I feel eHealth services are unnecessary } \\
\text { as I can contact my doctor by phone. }\end{array}$ & $\begin{array}{l}\text { Completely agree, Mostly agree, Neither } \\
\text { agree nor disagree, Mostly disagree, } \\
\text { Completely disagree, Don't know }\end{array}$ \\
\hline $\begin{array}{l}\text { Perception of } \\
\text { eHealth } \\
\text { Services }\end{array}$ & $\mathrm{F}$ & $\begin{array}{l}\text { I think electronic services are not } \\
\text { necessary as I can contact my } \\
\text { physician during phone hours. }\end{array}$ & $\begin{array}{l}1=\text { Completely disagree, } 2,3,4,5=\text { Completely } \\
\text { agree }\end{array}$ \\
\hline
\end{tabular}




\begin{tabular}{|c|c|c|c|}
\hline Variable & Country & Question & Answer \\
\hline $\begin{array}{l}\text { Perception of } \\
\text { eHealth } \\
\text { Services }\end{array}$ & $\mathrm{N}$ & $\begin{array}{l}\text { I prefer telephone to email when } \\
\text { contacting healthcare staff. }\end{array}$ & $\begin{array}{l}\text { Completely disagree }=1 \text { to Completely agree }= \\
\text { 4. Don't know }=5 \text {. }\end{array}$ \\
\hline $\begin{array}{l}\text { Perception of } \\
\text { eHealth } \\
\text { Services }\end{array}$ & $D$ & $\begin{array}{l}\text { I can easier get in touch with my care } \\
\text { provider. }\end{array}$ & $\begin{array}{l}\text { Completely agree, Mostly agree, Neither } \\
\text { agree nor disagree, Mostly disagree, } \\
\text { Completely disagree, Don't know }\end{array}$ \\
\hline $\begin{array}{l}\text { Perception of } \\
\text { eHealth } \\
\text { Services }\end{array}$ & $\mathrm{D}$ & $\begin{array}{l}\text { My care provider gets more time to } \\
\text { treat patients as minor issues can be } \\
\text { clarified through e-consultation. }\end{array}$ & $\begin{array}{l}\text { Completely agree, Mostly agree, Neither } \\
\text { agree nor disagree, Mostly disagree, } \\
\text { Completely disagree, Don't know }\end{array}$ \\
\hline \multicolumn{4}{|l|}{ Transparency } \\
\hline $\begin{array}{l}\text { Perception of } \\
\text { eHealth } \\
\text { Services }\end{array}$ & $\mathrm{D}$ & $\begin{array}{l}\text { It is important to me to be able to } \\
\text { follow my treatment. }\end{array}$ & $\begin{array}{l}\text { Completely agree, Mostly agree, Neither } \\
\text { agree nor disagree, Mostly disagree, } \\
\text { Completely disagree, Don't know }\end{array}$ \\
\hline $\begin{array}{l}\text { Perception of } \\
\text { eHealth } \\
\text { Services }\end{array}$ & $\mathrm{D}$ & $\begin{array}{l}\text { It is important to me to have access to } \\
\text { the notes I search for. }\end{array}$ & $\begin{array}{l}\text { Completely agree, Mostly agree, Neither } \\
\text { agree nor disagree, Mostly disagree, } \\
\text { Completely disagree, Don't know }\end{array}$ \\
\hline $\begin{array}{l}\text { Perception of } \\
\text { eHealth } \\
\text { Services }\end{array}$ & $D$ & $\begin{array}{l}\text { I am not interested to read } \\
\text { information about my treatment. }\end{array}$ & $\begin{array}{l}\text { Completely agree, Mostly agree, Neither } \\
\text { agree nor disagree, Mostly disagree, } \\
\text { Completely disagree, Don't know }\end{array}$ \\
\hline \multicolumn{4}{|l|}{ Collaboration } \\
\hline $\begin{array}{l}\text { Perception of } \\
\text { eHealth } \\
\text { Services }\end{array}$ & $\mathrm{D}$ & $\begin{array}{l}\text { It is important to me that all my care } \\
\text { providers can follow my health issues. }\end{array}$ & $\begin{array}{l}\text { Completely agree, Mostly agree, Neither } \\
\text { agree nor disagree, Mostly disagree, } \\
\text { Completely disagree, Don't know }\end{array}$ \\
\hline $\begin{array}{l}\text { Perception of } \\
\text { eHealth } \\
\text { Services }\end{array}$ & $\mathrm{D}$ & $\begin{array}{l}\text { I think that my treatment improved } \\
\text { when several care providers could } \\
\text { follow my health issues. }\end{array}$ & $\begin{array}{l}\text { Completely agree, Mostly agree, Neither } \\
\text { agree nor disagree, Mostly disagree, } \\
\text { Completely disagree, Don't know }\end{array}$ \\
\hline $\begin{array}{l}\text { Perception of } \\
\text { eHealth } \\
\text { Services }\end{array}$ & $\mathrm{D}$ & $\begin{array}{l}\text { That all health providers can follow my } \\
\text { health issues. }\end{array}$ & $\begin{array}{l}\text { Completely agree, Mostly agree, Neither } \\
\text { agree nor disagree, Mostly disagree, } \\
\text { Completely disagree, Don't know }\end{array}$ \\
\hline \multicolumn{4}{|l|}{ Trust } \\
\hline $\begin{array}{l}\text { Perception of } \\
\text { eHealth } \\
\text { Services }\end{array}$ & $\mathrm{D}$ & $\begin{array}{l}\text { It feels safe to be able to get in touch } \\
\text { with my caregiver from home. }\end{array}$ & $\begin{array}{l}\text { Completely agree, Mostly agree, Neither } \\
\text { agree nor disagree, Mostly disagree, } \\
\text { Completely disagree, Don't know }\end{array}$ \\
\hline $\begin{array}{l}\text { Perception of } \\
\text { eHealth } \\
\text { Services }\end{array}$ & $\mathrm{F}$ & $\begin{array}{l}\text { I don't trust producers of electronic } \\
\text { services. }\end{array}$ & $\begin{array}{l}1=\text { Completely disagree, } 2,3,4,5=\text { Completely } \\
\text { agree }\end{array}$ \\
\hline Security & & & \\
\hline $\begin{array}{l}\text { Perception of } \\
\text { eHealth } \\
\text { Services }\end{array}$ & $\mathrm{D}$ & My record does not disappear. & $\begin{array}{l}\text { Completely agree, Mostly agree, Neither } \\
\text { agree nor disagree, Mostly disagree, } \\
\text { Completely disagree, Don't know }\end{array}$ \\
\hline $\begin{array}{l}\text { Perception of } \\
\text { eHealth } \\
\text { Services }\end{array}$ & D & $\begin{array}{l}\text { I am nervous about the security } \\
\text { regarding my personal data. }\end{array}$ & $\begin{array}{l}\text { Completely agree, Mostly agree, Neither } \\
\text { agree nor disagree, Mostly disagree, } \\
\text { Completely disagree, Don't know }\end{array}$ \\
\hline $\begin{array}{l}\text { Perception of } \\
\text { eHealth } \\
\text { Services }\end{array}$ & $\mathrm{F}$ & $\begin{array}{l}\text { I am nervous about the security } \\
\text { regarding my personal data. }\end{array}$ & $\begin{array}{l}1=\text { Completely disagree, } 2,3,4,5=\text { Completely } \\
\text { agree }\end{array}$ \\
\hline $\begin{array}{l}\text { Perception of } \\
\text { eHealth }\end{array}$ & $\mathrm{N}$ & $\begin{array}{l}\text { Ifeel insecure when using Internet, } \\
\text { email or ehealth services. }\end{array}$ & $\begin{array}{l}\text { Completely disagree }=1 \text { to Completely agree }= \\
\text { 4. Don't know }=5 \text {. }\end{array}$ \\
\hline
\end{tabular}




\begin{tabular}{|c|c|c|c|}
\hline Variable & Country & Question & Answer \\
\hline $\begin{array}{l}\text { Perception of } \\
\text { eHealth } \\
\text { Services }\end{array}$ & $\mathrm{D}$ & $\begin{array}{l}\text { I am mainly concerned about misuse } \\
\text { of my care data in the public health } \\
\text { system. }\end{array}$ & $\begin{array}{l}\text { Completely agree, Mostly agree, Neither } \\
\text { agree nor disagree, Mostly disagree, } \\
\text { Completely disagree, Don't know }\end{array}$ \\
\hline \multicolumn{4}{|l|}{ Patient Safety } \\
\hline $\begin{array}{l}\text { Perception of } \\
\text { eHealth } \\
\text { Services }\end{array}$ & $\mathrm{D}$ & $\begin{array}{l}\text { Certain types of errors can be } \\
\text { prevented when it comes to } \\
\text { medication. }\end{array}$ & $\begin{array}{l}\text { Completely agree, Mostly agree, Neither } \\
\text { agree nor disagree, Mostly disagree, } \\
\text { Completely disagree, Don't know }\end{array}$ \\
\hline $\begin{array}{l}\text { Perception of } \\
\text { eHealth } \\
\text { Services }\end{array}$ & $\mathrm{F}$ & $\begin{array}{l}\text { I cannot be sure that errors regarding } \\
\text { e.g. my medication will be prevented. }\end{array}$ & $\begin{array}{l}1=\text { Completely disagree, } 2,3,4,5=\text { Completely } \\
\text { agree }\end{array}$ \\
\hline $\begin{array}{l}\text { Perception of } \\
\text { eHealth } \\
\text { Services }\end{array}$ & $\mathrm{N}$ & $\begin{array}{l}\text { I am concerned that my health status } \\
\text { is not available for healthcare staff in } \\
\text { an acute situation. }\end{array}$ & $\begin{array}{l}\text { Completely disagree }=1 \text { to Completely agree }= \\
\text { 4. Don't know }=5 \text {. }\end{array}$ \\
\hline Privacy & & & \\
\hline $\begin{array}{l}\text { Perception of } \\
\text { eHealth } \\
\text { Services }\end{array}$ & $\mathrm{F}$ & $\begin{array}{l}\text { I don't trust that my personal data will } \\
\text { be kept secret. }\end{array}$ & $\begin{array}{l}1=\text { Completely disagree, } 2,3,4,5=\text { Completely } \\
\text { agree }\end{array}$ \\
\hline $\begin{array}{l}\text { Perception of } \\
\text { eHealth } \\
\text { Services }\end{array}$ & $\mathrm{N}$ & $\begin{array}{l}\text { I am concerned that outsiders will get } \\
\text { access to my health data as they are } \\
\text { sent electronically. }\end{array}$ & $\begin{array}{l}\text { Completely disagree }=1 \text { to Completely agree }= \\
\text { 4. Don't know }=5 .\end{array}$ \\
\hline
\end{tabular}

- d) Future Requirements/Wishes

Questions regarding Future Requirements and Wishes were posed in Finland and Norway. Both used 5 -point Likert scales for rating the importance of different functionalities, services and features. Those could be categorized into "access to health data", "sharing of health data", "collaboration", and "administrative services" (Table 8).

Table 8: Future requirements/wishes questions, answers and variables used in the different countries

Variable Country $\quad$ Question $\quad$ Answer

\section{Future}

requirements/Wishes

$\begin{array}{lccl}\begin{array}{l}\text { Access To Health Data } \\ \text { Future } \\ \text { requirements/Wishes }\end{array} & F & \begin{array}{l}\text { To follow up on your health } \\ \text { (e.g. weight control, diet and } \\ \text { physical activity diary) }\end{array} & \begin{array}{l}1=\text { Not at all important, 2,3,4,5=Very } \\ \text { important }\end{array} \\ \begin{array}{l}\text { Future } \\ \text { requirements/Wishes }\end{array} & F & \begin{array}{l}\text { To follow up measurements/ } \\ \text { lab values (e.g. blood } \\ \text { pressure) }\end{array} & \begin{array}{l}1=\text { Not at all important, 2,3,4,5=Very } \\ \text { important }\end{array} \\ \begin{array}{l}\text { Future } \\ \text { requirements/Wishes }\end{array} & \mathrm{F} & \begin{array}{l}\text { Electronic risk tests and } \\ \text { information for self } \\ \text { management. }\end{array} & \begin{array}{l}1=\text { Not at all important, 2,3,4,5=Very } \\ \text { important }\end{array}\end{array}$


Variable

Future

requirements/Wishes

Future

requirements/Wishes

Future

requirements/Wishes

Future

requirements/Wishes

Future

requirements/Wishes

Future

requirements/Wishes

Sharing Health Data

Future

requirements/Wishes

requirements/Wishes

Future

requirements/Wishes

Collaboration

Future

requirements/Wishes

Future

requirements/Wishes

Future

requirements/Wishes

Future

requirements/Wishes

Future

requirements/Wishes

Administrative

Services

Future

requirements/Wishes

Future

requirements/Wishes

Future

requirements/Wishes

$\mathrm{F}$

$\mathrm{F}$

F

F

$\mathrm{F}$
Country Question

F Possibility to read and renew

prescriptions.

N

Possibility to order or renew prescriptions through email, Internet or SMS.

F Possibility to read your medical record.

$\mathrm{N} \quad$ Access to your medical record through the Internet.

Possibility to read your social care record.

Possibility to read your lab and radiology results including textual explanations.

Possibility to share data that you have collected yourself (e.g. blood sugar, blood pressure), and ask for advice and get instructions by your physician.

A personal health folder to store health and wellness data.

Participation in establishing care plan through the webb.

Possibility to keep contact with your health and social care providers through a secure Internet connection.

Possibility to have email contact

N

Consulting care providers through Internet

N

Participate in patient forums on the Internet.

Possibility to fill in different applications, templates and do administrative tasks through Internet.

F

Prohibit to use your health care data.
Answer

$1=$ Not at all important, $2,3,4,5=$ Very important

$1=$ Not at all important, $2,3,4,5=$ Very important

$1=$ Not at all important, $2,3,4,5=$ Very important

$1=$ Not at all important, $2,3,4,5=$ Very important

$1=$ Not at all important, $2,3,4,5=$ Very important

$1=$ Not at all important, $2,3,4,5=$ Very important

$1=$ Not at all important, $2,3,4,5=$ Very important

$1=$ Not at all important, $2,3,4,5=$ Very important

$1=$ Not at all important, $2,3,4,5=$ Very important

$1=$ Not at all important, $2,3,4,5=$ Very important

$1=$ Not at all important, $2,3,4,5=$ Very important

1 (högst osannolikt) till 5 (högst sannolikt)

1 (högst osannolikt) till 5 (högst sannolikt)

$1=$ Not at all important, $2,3,4,5=$ Very important

$1=$ Not at all important, $2,3,4,5=$ Very important

$1=$ Not at all important, $2,3,4,5=$ Very important 


\begin{tabular}{|c|c|c|c|}
\hline Variable & Country & Question & Answer \\
\hline $\begin{array}{l}\text { Future } \\
\text { requirements/Wishes }\end{array}$ & $\mathrm{F}$ & $\begin{array}{l}\text { Possibility to give feedback } \\
\text { on e-services electronically. }\end{array}$ & $\begin{array}{l}1=\text { Not at all important, } 2,3,4,5=\text { Very } \\
\text { important }\end{array}$ \\
\hline $\begin{array}{l}\text { Future } \\
\text { requirements/Wishes }\end{array}$ & $\mathrm{F}$ & $\begin{array}{l}\text { Electronic response from } \\
\text { other patients or clients. }\end{array}$ & $\begin{array}{l}1=\text { Not at all important, } 2,3,4,5=\text { Very } \\
\text { important }\end{array}$ \\
\hline $\begin{array}{l}\text { Future } \\
\text { requirements/Wishes }\end{array}$ & $\mathrm{F}$ & $\begin{array}{l}\text { Reporting patient harms and } \\
\text { side effects. }\end{array}$ & $\begin{array}{l}1=\text { Not at all important, } 2,3,4,5=\text { Very } \\
\text { important }\end{array}$ \\
\hline $\begin{array}{l}\text { Future } \\
\text { requirements/Wishes }\end{array}$ & $\mathrm{F}$ & $\begin{array}{l}\text { Possibility to fill in surveys } \\
\text { and evaluations } \\
\text { electronically. }\end{array}$ & $\begin{array}{l}1=\text { Not at all important, } 2,3,4,5=\text { Very } \\
\text { important }\end{array}$ \\
\hline $\begin{array}{l}\text { Future } \\
\text { requirements/Wishes }\end{array}$ & $\mathrm{F}$ & $\begin{array}{l}\text { A registry to help getting a } \\
\text { place at a healthcare } \\
\text { institution. }\end{array}$ & $\begin{array}{l}1=\text { Not at all important, } 2,3,4,5=\text { Very } \\
\text { important }\end{array}$ \\
\hline $\begin{array}{l}\text { Future } \\
\text { requirements/Wishes }\end{array}$ & $\mathrm{F}$ & $\begin{array}{l}\text { Electronic appointment } \\
\text { booking for healthcare. }\end{array}$ & $\begin{array}{l}1=\text { Not at all important, } 2,3,4,5=\text { Very } \\
\text { important }\end{array}$ \\
\hline $\begin{array}{l}\text { Future } \\
\text { requirements/Wishes }\end{array}$ & $\mathrm{N}$ & $\begin{array}{l}\text { Possibility to use Internet for } \\
\text { appointment booking and } \\
\text { cancelling. }\end{array}$ & $\begin{array}{l}1=\text { Not at all important, } 2,3,4,5=\text { Very } \\
\text { important }\end{array}$ \\
\hline $\begin{array}{l}\text { Future } \\
\text { requirements/Wishes }\end{array}$ & $\mathrm{F}$ & $\begin{array}{l}\text { Electronic appointment } \\
\text { booking for social care. }\end{array}$ & $\begin{array}{l}1=\text { Not at all important, } 2,3,4,5=\text { Very } \\
\text { important }\end{array}$ \\
\hline $\begin{array}{l}\text { Future } \\
\text { requirements/Wishes }\end{array}$ & $\mathrm{F}$ & $\begin{array}{l}\text { SMS reminder prior to } \\
\text { appointment. }\end{array}$ & $\begin{array}{l}1=\text { Not at all important, } 2,3,4,5=\text { Very } \\
\text { important }\end{array}$ \\
\hline $\begin{array}{l}\text { Future } \\
\text { requirements/Wishes }\end{array}$ & $\mathrm{N}$ & $\begin{array}{l}\text { Possibility to receive SMS } \\
\text { reminders prior to } \\
\text { appointment. }\end{array}$ & $\begin{array}{l}1=\text { Not at all important, } 2,3,4,5=\text { Very } \\
\text { important }\end{array}$ \\
\hline $\begin{array}{l}\text { Future } \\
\text { requirements/Wishes }\end{array}$ & $\mathrm{N}$ & $\begin{array}{l}\text { Information about physician } \\
\text { office, waiting lists, } \\
\text { physician qualifications etc. }\end{array}$ & $\begin{array}{l}1=\text { Not at all important, } 2,3,4,5=\text { Very } \\
\text { important }\end{array}$ \\
\hline \multicolumn{4}{|l|}{ Other } \\
\hline $\begin{array}{l}\text { Future } \\
\text { requirements/Wishes }\end{array}$ & $\mathrm{F}$ & $\begin{array}{l}\text { That general information } \\
\text { and care recommendations } \\
\text { are based on reliable } \\
\text { sources. }\end{array}$ & $\begin{array}{l}1=\text { Not at all important, } 2,3,4,5=\text { Very } \\
\text { important }\end{array}$ \\
\hline $\begin{array}{l}\text { Future } \\
\text { requirements/Wishes }\end{array}$ & $\mathrm{N}$ & $\begin{array}{l}\text { Search for health } \\
\text { information on the Internet }\end{array}$ & 1 (högst osannolikt) till 5 (högst sannolikt) \\
\hline
\end{tabular}

\subsubsection{Country comparison}

When analysing the questionnaires from 2013 it became clear that there were few data variables that were actually measured in the same way in the different Nordic countries and where data could thus be compared. However, there were a number of commonalities between the surveys. For example, there exists a stable common set of background and health variables, while certain categories for eHealth variables could be defined where questions are asked in the same way. These are questions related to internet use in general and the use of specific types of eServices or functionalities. We can see a tendency for some indicators to disappear (e.g. questions about use of specific eServices where access is now logged instead) and we see a trend towards more 
indicators for measuring consumer perception of eHealth services in the form of advantages and disadvantages, as well as future requirements. There is a tendency to go from accessing data to sharing data and Finland already includes questions about social care in their surveys, whereas the other countries restrict questions to healthcare. Since the construction of the questionnaires in 2013, the work in the individual Nordic countries has of course been further developed, partly on the basis of our country comparisons. How the work has progressed in the individual countries is described in the following sections.

\section{Denmark}

In Denmark, data on citizens' use of eHealth are monitored by different stakeholders, either through service-specific logging or in respect of the motivation for using specific services. The National Health Service Portal www. Sundhed.dk do surveys on the use of the specific portal, while the National Statistical Office monitors, for example, the availability of hardware, infrastructures etc. The only national survey on citizens' use of and attitude towards eHealth is done by the Danish eHealth observatory (an NGO). They finance a bi-annual survey, which started in 2013. Since the collection of data for the current project, Denmark has benefitted from the cooperation between the Nordic countries when reviewing the 2013 survey. During that process, we were able to plan for a larger indicator alignment with the other countries and learn from, for example, the Norwegian survey to add questions on the citizen's engagement with producing patient generated health data by the use of self-monitoring devices. From the Finnish survey, we were inspired to include questions on social matters, for example, on whether the respondent was a person primarily responsible for helping a fragile relative or friend with their health-sector encounters. These data, among others, point in the direction of an even larger alignment of the Nordic citizen's surveys and future comparisons of data. In 2017, Denmark will repeat the 2015 survey with only minor adjustments.

Finland

In comparison to the 2014 survey, the Finnish citizens' eHealth survey will be conducted as a single module in the Finnish ATH-survey (Vuxenbefolkningens hälsa, välfärd och service (ATH, abbreviation from the Finnish name) conducted by the National Institute for Health and Welfare (THL). This means that the eHealth questions on the 2017 survey are limited to 2 pages on the one hand, but on the other, responses can be combined with a vast amount of background, health and service-use data from the basic ATHsurvey. The 2-page set contains the following key questions from the previous survey:

- Mode of use of key health- and welfare-related functions (traditional/ electronical) + estimate on no. of traditional transactions saved per year if electronical.

- Mode of using services on behalf of others.

- Benefits of and Barriers to use. 
- Importance of key eHealth functions (for: health and welfare promotion; selfassessment; service selection; transaction services).

New questions inspired by the Nordic survey comparison include rating the importance of a list of potential key benefits and estimated proficiency in the use of online eServices.

Iceland

Iceland has not been conducting citizen eHealth surveys and hence, no survey questions were available from Iceland for comparisons. However, the Directorate for Health in Iceland will be conducting a citizen eHealth survey for the first time in 2017. The questionnaire will be guided and based on the results and recommendations of the NeRN work on common eHealth indicators and data will be collected in parallel with the Finnish citizen survey. Iceland has however been collecting national log data on citizen's use of available eHealth services ever since the national citizen health portal was launched in October of 2014.

\section{Norway}

In Norway the citizens' eHealth survey has not been conducted since 2013. An assessment and revision of the survey (content and organisation) is planned in connection with overall eHealth monitor planning, currently being organised as a project-collaboration between the Directorate for eHealth and the NSE.

\section{Sweden}

When collecting data for this project in 2015 , only two national patient surveys existed for Sweden $(5,6)$. Those surveys included a very few eHealth-related questions, mainly about internet use in general. Since more patient eServices have become available in Sweden, the development of instruments to capture patient perspectives increases as a consequence. There is, however, no national coordination to date on the collection of patient and citizen perspectives on eHealth. Most data collection is done at a regional level by different county councils and regions evaluating their regional implementation of the patient portal and patient's access to their health record or in the form of different research projects (7-8). Access logs to different citizen eServices are published by Inera (9).

\subsubsection{Towards a common Nordic model survey}

Based on the country comparisons and as we can see from the ongoing work in the different Nordic countries, there is clearly a potential to measure new indicators in this area. The analysis of the surveys has shown that there is a general interest in measuring effects and preferences regarding the use and re-use of eHealth to sample information, interact with health and social care services and to, in parallel, increase patient empowerment. While some countries started collecting data some years ago, others are still in the process of developing surveys that measure the use of eHealth. 
It is, however, difficult to know, with the information we have had access to, how individuals have understood the surveys and if they have measured what they were intended to measure. We have had limited access to the answers sampled in the different countries.

The idea of "being digital" and using eHealth services as a tool to stimulate empowerment of individuals with the same quality level as today has been a reality for all the Nordic countries. However, for different reasons, the digitalization of the eHealth area has not yet constituted a sustainable digital alternative. The degree of digitalization has combined both physical and digital resources but, from the surveys it seems that a real digital capability has not yet been realized. Differences in the level of implementation and the use of eHealth applications are reflected in the surveys. An interesting issue is that none of the surveys asked about the IT-maturity of the end-users or for eventual constraints i.e. disabilities that could influence the possibility to access, use and trust eHealth services. Experiences sampled from other areas have shown that this is indeed a factor that influences the use and sustainability of digital services.

After analysing and discussing the current questionnaires, we will work further at the establishment of a common Nordic model survey and propose additional common questions such as:

Tentative new background variables

- Preferred platform to be used for accessing/using eHealth services.

- Preferred language.

- eHealth literacy.

- Variables related to the socioeconomic status of the respondents.

Tentative additional eHealth variables

- Variables that can support and increase confidence in the use of eHealth services. Examples of such variables that could be asked for in the form of required functionalities are:

- Different types of reminders i.e.:

- today there is a high-cost ceiling electronically, individuals may want to know when they are approaching the limit

- electronic reminders for renewal of prescription

- SMSs sent to individuals at the moment someone has read or updated the EHR.

- Administrative eServices regarding access rights, for instance:

- electronic signature

- ability to restrict individual information related to personal integrity in respect of different devices (e.g. related to sex, religion etc.)

- allow storage of data / information in different registers

- participating in research studies. 
- Personalisation of services.

- Possibility or need to adapt the services to some disability, i.e. if the individual needs to receive the information as text, in images etc.

- Information about options or alternatives if the individual prefers not to use eHealth services.

- Information about rules, restrictions, support in the event they choose to use private providers/ suppliers of eHealth services instead of i.e. 1177 services.

- Questions about advantages and disadvantages of consumer eHealth services.

- Outcome variables related to patient-reported outcome measures (PROM) and patient-experienced outcome measures (PREM), as well as clinical measures for value-based healthcare.

\subsection{Conclusions}

Many of today's health consumers are active and informed decision-makers. Consumers/patients worldwide are changing their behaviours due to a combination of patient-centred health technologies and services, access to vast quantities of clinical information, and stronger incentives putting them "on the hook" for playing an active role in their own health care. There is however a difference in the use of eHealth services that can be linked to a difference in socioeconomic status. The higher the educational level is the better the compliance. This is an important issue to consider in further research.

In future studies, it will also be necessary to focus on specific areas that the health and social care systems aim or plan to improve with the help of eHealth services. It will be necessary to identify specific needs of groups of patients, especially those who are suffering from long-term diseases. As of today there is a lack of knowledge regarding whether some services should be provided by health organisations to specific groups or not. An important pre-condition to increase the use of eHealth services is to design the technology and the service to meet the need of the intended beneficiaries, as well as to inform citizens about policies and guidelines. To conduct and jointly monitor the next Nordic surveys and to sample accurate data that will help to identify the next steps, requirements, pre-requisites for using eHealth services, and the incentives to use these services, it will be necessary to balance information about individuals' understanding and expectations from the provided services, its value, its quality and its importance for a care process. Even when it is theoretically possible to measure use and re-use available eHealth services, future surveys are at risk of having a bias in the number and clustering of respondents. Future studies have to either be performed after a basket of services are implemented to evaluate their use and the effects of the adoption of this, or to focus on specific groups of patients or socioeconomic groups of citizens that are supposed to be long-term users of eHealth services. 


\section{$5.4 \quad$ References}

(1) Danish questionnaire, 2013

http://www.dachi.aau.dk/digitalAssets/131/131627_14_2_undersoegelse_af_borgernes_anven delse_af_sundheds-it_i_2013.pdf

(2) Finnish questionnaire, 2013 (survey conducted in 2014). Available in http://www.thl.fi/attachments/SADeSote/Annex\%201.\%20Citizens\%2oexperiences $\% 200 f \% 2$ oelectronic\%2oservices\%2oin\%2othe\%2ososial\%2owelfare\%2oand\%2ohealth\%2ocare.pdf

(3) Norwegian questionnaire, 2007.

(4) Norwegian questionnaire, 2013.

(5) Nationell Patientenkät/National Patient Survey, Sweden, 2013 https://patientenkat.se/sv/english/

(6) Vårdbarometer/Care Barometer, Sweden, 2013 http://vardbarometern.nu/

(7) DOME Deployment of Online Medical Records and eHealth services https://projectdome.wordpress.com/

(8) My Care Pathways http://ki.se/en/lime/my-care-pathways

http://www.inera.se/INVANARTJANSTER/

(9) Inera: http://www.inera.se 



\section{6. eHealth indicator work worldwide - steps in collaboration with the OECD, WHO and EU}

\subsection{Introduction}

This chapter presents the results of the work conducted in Mandate period 3 related to NeRN collaboration with the WHO, EU and the OECD. The following questions were set to be answered:

- What are the OECD, WHO and EU doing in relation to eHealth monitoring and what are their plans for future eHealth indicator work?

- To what extent do these coincide with the NeRN work?

- What are the possibilities for NeRN to collaborate with the OECD, WHO and EU in the development of a system of collecting, analysing and publishing indicator data and/or testing common indicators for eHealth services, with considerations for both patients and citizens' point of view?

\subsection{Materials and methods}

Materials to answer the questions are listed in the references-section of this chapter. The following methods were used to analyse the material:

- Content analysis of the EU, WHO and OECD documents (1-9) having a key focus on eHealth policies and monitoring, using a qualitative data analysis programme AtlasTI in the context of the EU JAseHN-project.

- Feeding the preliminary results into common discussions in the NeRN meetings with the $\mathrm{WHO}$ and $\mathrm{EU}$ delegates.

- Identification and analysis of the EU Horizon 2020-ongoing eHealth projects to identify the eHealth projects that have been accepted for funding by $\mathrm{H}_{2} \mathrm{O} 2 \mathrm{O}$, and to study the characteristics of the proposals. Identification of accepted $\mathrm{H}_{2} \mathrm{O} 2 \mathrm{O}$ eHealth projects was done by means of Google search and a search of the $\mathrm{H}_{2} \mathrm{O} 2 \mathrm{O}$ web portal https://ec.europa.eu/programmes/horizon2020/, as well as with the report: "eHealth projects. Research and Innovation in the field of ICT for health and well being", http://www.eHealthnews.eu/images/stories/pdf/research-and-

innovation-in-eHealth-June-2016.pdf 


\subsection{Collaboration with the OECD task forces}

The NeRN network collaborated with the OECD in the development and testing of the OECD model survey from 2012-2015. The model survey focuses on the availability and use of EHR, HIE and PHR functionalities. The OECD does not collect data themselves; instead member states integrate the commonly agreed questions into their national surveys.

To publish the results of piloting of the model survey, the OECD led preparation of a JAMIA paper on International Health IT Benchmarking: Learning from Cross-Country Comparisons. Denmark and Finland participated in the paper as NeRN-authors, and the NeRN collaboration and results were promoted through the article. The article was published in August 2016 (10). A variety of next steps for the OECD were planned in the article, including:

- Further analysis of pilot data and the pilot process with a view to sharing key findings with pilot country participants, OECD forums, and the broader community.

- Exploring options for expanding participation in cross-national benchmarking, e.g. via the United Nations Economic Commission for Latin America and the Caribbean, and some countries advancing regional benchmarking opportunities (e.g. the Nordic countries, Latin America, Germany and Austria).

- Tracking country-level plans to further advance the model survey and benchmarking activities.

- Identifying opportunities for advancing the model survey and associated indicators based on feedback from the pilot, country experiences with national data collection, and potential emerging trends and policy priorities (e.g. mHealth).

- A number of countries or groups of countries have also planned to achieve progress with benchmarking efforts. For instance, the Nordic countries plan to continue their collaboration by developing common health ICT usability and outcome indicators in countries with advanced National Health ICT Infrastructures, to be considered by the OECD in the future.

The OECD work has continued in the form of a meeting on "Mobile technology-based services for global health and wellness: Opportunities and challenges' at Harvard Mobile Technologies for Health and Wellness on 5-6 October 2016 in Boston, Mass. USA. The consultation was co-sponsored by the Harvard Global Health Institute, Swedish Vinnova, Canada Health Infoway, and the Global Coalition on Aging. The aim of the consultation was to examine the priority policy needs and the possible feasible avenues for progress in measurements that could better inform policy analysis in those priority areas and to further the international dialogue on issues critical to the successful adoption of mobile-technology-based services for health and wellness. The objectives were to: 
- Review trends in OECD and non-OECD countries.

- Discuss lessons learnt and identify key policy challenges in leveraging mHealth to support health system priorities and Universal Healthcare.

- Discuss relevant frameworks and recommendations on data governance and risk management practices and offer perspectives on what work is needed to promote their implementation.

- Agree a framework and actions that the OECD can undertake in the short- and medium-term to support a measurement agenda for evidence-based policy.

The NeRN network members who participated in the OECD model survey development were invited to the meeting. The agenda and an invitation were circulated through formal channels to the Health Committee and $\mathrm{HCO}$ delegates, and separately by the leader of the OECD model survey development. The OECD aim has been to launch with the meeting a future chapter in the OECD benchmarking initiative.

During the meeting a number of international experts reviewed global trends and presented examples of applications in OECD and non-OECD countries for prevention, health promotion, diagnosis, access to treatment, treatment adherence, monitoring pharmacovigilance and disease.

A very useful overview was presented by Maeghan Orton from the WHO. In a WHO \& UNICEF Framework on mHealth for Health System Strengthening. This framework lists 12 common mHealth application areas that have been vetted through multiple iterations - see Figure 9.

Figure 9: 12 common mHealth and ICT applications*

\begin{tabular}{|c|c|}
\hline $\begin{array}{l}\text { Client education \& behaviour change } \\
\text { communication (BCC) }\end{array}$ & $\begin{array}{l}\text { Provider-to-provider communication } \\
\text { User groups, consultation }\end{array}$ \\
\hline Sensors \& point-of-care diagnostics & Provider workplanning \& scheduling \\
\hline Registries / vital events tracking & Provider training \& education \\
\hline Data collection and reporting & Human resource management \\
\hline Electronic health records & Supply chain management \\
\hline $\begin{array}{l}\text { Electronic decision support } \\
\text { Information, protocols, algorithms, checklists }\end{array}$ & Financial transactions \& incentives \\
\hline
\end{tabular}

Note: $\quad$ *Labrique $A B$, Vasudevan L, Kochi E, Fabricant R, Mehl G. mHealth innovations as health system strengthening tools (11). : 12 common applications and a visual framework. Global Health: Science and PracTIce. 2013 Aug 15;1(2):160-71.

Most mHealth applications deploy a package of two or more applications, and often make use of more smart phone applications, such as SMS, MMS, and IVR (Interactive Voice Response). To explore what measurements are needed for evidence-based policy, David Bates, of Brigham and Women's Hospital, Boston, set out the following questions in order to characterize the value of apps: 
- Does the app improve health?

- Does the app meet the needs of the patient?

- Do consumers find the app useful?

- Would a doctor recommend this app?

- Is the app safe?

To explore these questions a number of methods can be relevant: a literature study, Interviews with experts, app review, and usability studies. After having presented the evidence he concluded:

- Apps have the potential to improve healthcare.

- Apps also have the potential to cause harm as they become increasingly integrated with the healthcare system.

- What if low blood glucose values not recorded?

- What if no one is alerted about suicidal ideation?

- Not being directed at patients who can benefit the most from them.

- Level of evidence to date with reference to the benefit is limited.

- Apps are hard to use for patients with chronic illnesses.

- But patients do want them!

- Key frontiers.

- Linking mobile apps with EHRs and PHRs.

- Obtaining wearable data and sifting through it.

For the continuing work on mHealth technologies there are a number of points to pay attention to:

- Quality.

- Even more important and very big gaps.

- Literature is lacking.

- Safety.

- Clearly problems and some standards or best practices are needed.

- Privacy not yet adequately addressed.

- Patient engagement.

- Lots of room for improvement - little gamification, use of social media approaches. 
During the consultation, it became very clear that monitoring mHealth technologies is significantly more complex than monitoring conventional stationary ICT applications in the health care system. First, there is usually more functionalities in each application. Second, there are serious problems with safety issues, since clear standards are nonexistent. Third, the quality of the apps varies dramatically. Measuring diffusion and use under these conditions is going to suffer from serious reliability and validity problems. As a suggestion, Robin Osborn, Vice President and Director, Commonwealth Fund, US, pointed at the need to obtain measures on:

- Access to care.

- Care coordination and transitions.

- Management of chronic conditions and self-management support.

- Patient-centred care.

- Health promotion.

These variables will focus directly on outcome measures, and can have a high value in regard to better informing policy analysis and establishing an evidence-based mHealth policy. Slides and material from the consultation can be found online (12).

\subsection{Overview of OECD Studies on eHealth vs. the EU eHealth action plan}

Participation in the eHealth Network (eHN) Joint Action (JAseHN, http://jasehn.eu/) project offered a chance to boost the collaboration with the EU and the OECD. The JAseHN-project runs from 2015 to 2018, and is funded by the Grants for actions, cofinanced by member state authorities (Joint Actions), 3rd EU Health Programme. The sole objective of JAseHN is to act as the main preparatory body for the eHealth Network (eHN). The eHealth Network mandate derives from the eHealth Action Plan (13) and provisions of Article 14, which institutes the legal basis for policy cooperation on eHealth at EU level. There are four foci in the plan for 2014-2018: (1) Interoperability \& standardisation; (2) Exchange of knowledge (3) Monitoring \& assessment of implementation (4) Global cooperation \& positioning. JAseHN aims to develop political recommendations and other instruments for cooperation in these four specific priority areas (listed above) that are defined in the eHN's Multiannual Work Plan (MWP).

THL led one task in the project, which was closely related to eHealth benchmarking. The aim was to analyse OECD studies in order to identify eHealthrelated policy goals and study results. The OECD study foci and results were considered in light of the EU eHealth Action Plan for the basis of developing recommendations for cooperation. The work was conducted by $\mathrm{HH}$ and $\mathrm{PH}$ in Finland. Below are the key findings related to policy goals, monitoring and benchmarking, and global cooperation.

The full report ( $D$ 8.1.1) has been published on the JAseHN website (19). The analysis showed that the most important policy targets mentioned in the OECD studies 
were healthcare system efficiency, "value for money" and high quality of care as an outcome of value for money. The variety of healthcare ICT-specific policy targets were more scattered. According to the studies, ICT's most important role in policies is as a contributor of tools or a provider of data for healthcare system measurement and quality improvement (secondary use of health data). Promoting the use (availability and usage rate) of EHR's and other ICT is also a policy priority. Data governance and assuring privacy strongly focus on the secondary use issues. Innovative "smarter systems", patient empowerment and integrated care are also found in some policy statements. Compared to the Nordic eHealth policy analysis, there are many similarities (Table g).

Table 9: Comparing the Nordic policy targets with the eHealth policy targets in the OECD reports

$\begin{array}{ll}\text { Nordic eHealth policy targets } & \text { eHealth policy targets in the OECD reports } \\ \text { Availability, update-ability of eHealth services } & \text { (Availability and) use of EHRs and other ICT } \\ \text { Use and utility for end users } & \text { HC system measurement and quality improvement } \\ \text { Use and utility for health system } & \text { Use of EHRs and other ICT (main focus on secondary use) } \\ \text { Trustability } & \text { Privacy } \\ \text { Shared information infrastructures (interoperability) } & \text { Integrated care } \\ \text { Improving the healthcare services } & \text { Innovative smarter systems } \\ \text { Empowering and activating citizens } & \text { Patient empowerment }\end{array}$

Part of a policy is the choice of implementation mechanisms. One of these mechanisms is monitoring and benchmarking the eHealth implementation progress. The OECD interest in eHealth monitoring and benchmarking is based on the insufficiency of existing evidence to clearly define who pays for and who benefits from health information technology implementation. The OECD has focused on developing common tools (the model survey) and indicators for benchmarking to be implemented by member states. The data on commonly agreed OECD eHealth indicators are collected by national bodies as part of countries' own benchmarking. Development of the OECD model survey was guided by three overarching principles:

- Measures needed to respond to policy and information needs of countries along a continuum, starting from ICT availability, moving towards effective use, and ending with measuring outcomes and impact on population health.

- The OECD "model survey" framework was used, composing the survey of separate, self-contained modules.

- A functionality-based approach to defining key types of health ICTs was to be used (6).

The EU is also interested in eHealth benchmarking. It is stated in the eHealth Action Plan (13), that from 2013 the Commission shall enhance its work on data collection and benchmarking activities in healthcare with relevant national and international bodies to include more specific eHealth indicators and assess the impact and economic value of eHealth implementation. 
Based on this, the EU has conducted eHealth benchmarking (availability and use) as separate studies (hospital and primary care benchmarking) twice (14). Benchmarking is, however, not mentioned as a systematic activity on the multiannual EU work plan agenda. The contents of the OECD and EU tools are not identical, whereby a comparison is not without problems.

The OECD is also interested in eHealth maturity. The OECD reports offer some indicators for health data maturity (related to content and use of data) and a taxonomy for assessing the maturity of HIE (Tables 10-11).The WHO has expressed interest in collaborating with the NeRN network towards common measures for eHealth maturity. 
Table 10: Key national health dataset availability, maturity and use according to the OECD report (2)

\begin{tabular}{|c|c|c|c|c|c|c|c|}
\hline & $\begin{array}{l}\% \text { of key } \\
\text { national health } \\
\text { datasets } \\
\text { available }^{1}\end{array}$ & $\begin{array}{l}\% \text { of health care } \\
\text { datasets with } \\
\text { coverage of } 80 \% \text { or } \\
\text { more of the } \\
\text { population }\end{array}$ & $\begin{array}{l}\% \text { of available health } \\
\text { care datasets where data } \\
\text { extracted automatically } \\
\text { from electronic clinical or } \\
\text { administrative records }\end{array}$ & $\begin{array}{l}\% \text { of available } \\
\text { datasets sharing } \\
\text { the same unique } \\
\text { patient ID }\end{array}$ & $\begin{array}{l}\% \text { of available datasets } \\
\text { where standard codes } \\
\text { are used for clinical } \\
\text { terminology }\end{array}$ & $\begin{array}{l}\% \text { of available datasets } \\
\text { used to regularly report on } \\
\text { health care quality or } \\
\text { health system performance } \\
\text { (published indicators) }\end{array}$ & $\begin{array}{l}\% \text { of available datasets } \\
\text { regularly linked for } \\
\text { research, statistics and/or } \\
\text { monitoring (indicators) }\end{array}$ \\
\hline Canada & $71 \%$ & $60 \%$ & $63 \%$ & $50 \%$ & $100 \%$ & $100 \%$ & $70 \%$ \\
\hline Czech Rep & $50 \%$ & $50 \%$ & $60 \%$ & $86 \%$ & $100 \%$ & $71 \%$ & $71 \%$ \\
\hline Denmark & $86 \%$ & $90 \%$ & $78 \%$ & $92 \%$ & $100 \%$ & $75 \%$ & $50 \%$ \\
\hline Finland & $79 \%$ & $90 \%$ & $44 \%$ & $100 \%$ & $89 \%$ & $55 \%$ & $91 \%$ \\
\hline Iceland & $79 \%$ & $90 \%$ & $90 \%$ & $100 \%$ & $100 \%$ & $91 \%$ & $90 \%$ \\
\hline Israel & $64 \%$ & $55 \%$ & $67 \%$ & $89 \%$ & $83 \%$ & $100 \%$ & $89 \%$ \\
\hline Italy & $64 \%$ & $70 \%$ & $86 \%$ & $44 \%$ & $100 \%$ & $100 \%$ & $44 \%$ \\
\hline Japan & $71 \%$ & $68 \%$ & $86 \%$ & $50 \%$ & $86 \%$ & $20 \%$ & $0 \%$ \\
\hline Korea & $79 \%$ & $80 \%$ & $88 \%$ & $91 \%$ & $100 \%$ & $82 \%$ & $73 \%$ \\
\hline Netherlands & $57 \%$ & $50 \%$ & $83 \%$ & $56 \%$ & $86 \%$ & $67 \%$ & $56 \%$ \\
\hline New Zealand & $57 \%$ & $59 \%$ & $86 \%$ & $75 \%$ & $83 \%$ & $100 \%$ & $75 \%$ \\
\hline Norway & $100 \%$ & $50 \%$ & $79 \%$ & $93 \%$ & $100 \%$ & $50 \%$ & $57 \%$ \\
\hline Singapore & $71 \%$ & $80 \%$ & $88 \%$ & $100 \%$ & $88 \%$ & $70 \%$ & $90 \%$ \\
\hline Spain & $36 \%$ & $30 \%$ & $75 \%$ & $67 \%$ & $100 \%$ & $100 \%$ & $67 \%$ \\
\hline Sweden & $86 \%$ & $90 \%$ & $89 \%$ & $83 \%$ & $89 \%$ & $67 \%$ & $67 \%$ \\
\hline United States & $64 \%$ & $13 \%$ & $57 \%$ & $64 \%$ & $86 \%$ & $73 \%$ & $55 \%$ \\
\hline England & $64 \%$ & $28 \%$ & $100 \%$ & $78 \%$ & $100 \%$ & $44 \%$ & $89 \%$ \\
\hline Scotland & $57 \%$ & $61 \%$ & $88 \%$ & $100 \%$ & $75 \%$ & $100 \%$ & $78 \%$ \\
\hline Wales & $64 \%$ & $65 \%$ & $100 \%$ & $100 \%$ & $100 \%$ & $44 \%$ & $89 \%$ \\
\hline
\end{tabular}

Note: $\quad$ 1. Includes hospital in-patient data, mental hospital in-patient data, emergency health care data, primary care data, prescription medicines data, cancer registry data, diabetes registry data, cardiovascular disease registry data, formal long-term care data and mortality data.

Source:

Authors own calculations based on the results of this study. 
Table 11: CITL taxonomy for HC information exchange and interoperability (5)

\section{Level Attributes}

$1 \quad$ Non-electronic data - no use of ICT to share information. The most commonly used manual process for sharing information is either in writing or orally. Human facilitation is exclusively relied upon to aggregate, review, and abstract data from paper sources.

Examples: postal mail, phone.

2 Machine transportable data - transmission of non-standard information via basic ICT; information within the document cannot be electronically manipulated. Clinicians can access the information, but no computerised data processing or logic can be applied.

Examples: PC- based exchange of scanned documents or manual faxing, pictures, portable document format (PDF).

3 Machine-organisable data - transmission of structured messages containing non-standardised data; requires multiple interfaces that can translate incoming data from the each of the sending organisation's vocabulary to the receiving organisation's vocabulary; usually results in imperfect translations because the vocabularies used have incompatible levels of detail. Data content is indexed down to single fields, however human translation is required to convert actual data in each field from the vocabulary of the sending organisation to that of the receiving organisation.

Examples: secure e-mail of free text, or PC-based exchange of files in incompatible/proprietary file formats, $\mathrm{HL}-7$ messages.

$4 \quad$ Machine-interpretable data - transmission of structured messages containing standardised and coded data; the ideal situation in which all systems exchange information using the same formats and vocabularies. All systems exchange data using the same messaging, format, and content standards, removing the need for multiple customised interfaces. All content can be extracted and converted electronically in each field and no longer requires human intervention.

Examples: automated exchange of coded results from an external lab into a provider's EMR, automated exchange of a patient's "problem list".

Source: Center for Information Technology Leadership; Walker et al. (2005).

One of the key eHealth policy goals found in the OECD studies was secondary use of health data for healthcare system measurement and quality improvement. Secondary use of health data is also high on the agenda in the Nordic eHealth policies. Prerequisites for secondary use are adequate data quality: completeness (e.g. in terms of population coverage), consistency (e.g. harmonious use of common terminology and coding); use of standards to ensure data linkages and interoperability; and enabling privacy-protective data use. The OECD study analysis revealed that even though standards are necessary, they are not a sufficient means to ensure data linkages, since there is no consensus on which standards should be implemented and how, leading to inconsistent medical terminology, clinical records, and data storage, which creates a barrier to the linkages of data from different sources.

The OECD studies emphasise eHealth governance that focuses on interoperability and standardisation as key elements for ensuring privacy protected availability of patient data to improve healthcare performance. However, the OECD model survey does not contain questions on interoperability, standardisation or privacy related to secondary use per se, only on generic availability of information exchange functionalities outside of organisations. The NeRN-network defined implementation of national information structures serves as one common Nordic eHealth interoperability indicator, and an indicator measuring the proportion of organisations with a written security plan serves as one common Nordic eHealth security (privacy) indicator. 
The EU plans to enhance interoperability and standardisation are reflected in the EU eHealth benchmarking activities in the form of one specific question: Question 34 . Which standards does your system support or comply with? In addition, there are questions on information exchange and data protection (14).

The OECD studies showed several benefits of Health ICTs, including 1) increase the safety of medical care, 2) improve workflows by facilitating administrative and clinical tasks, such as medication reconciliation, and by bringing DSS to the point of care, 3) reduce operating costs of clinical services, 4) reduce administrative costs, 5) achieve "transformation" of care by providing means to implement changes that are otherwise impossible, by improving access to care (telemedicine), improving chronic care, multiple service delivery and care coordination, and improving feedback on quality of care for clinicians who can adjust their working practice as appropriate. There are, however, no benefit indicators in the OECD surveys. The OECD has developed indicators for healthcare quality and efficiency for 10 years, which are the main goals also in eHealth implementation. To our knowledge, there is no plan to utilize these in monitoring eHealth benefits.

On the EU-level, the eHealth Network Multi-Annual Work Plan section (MWP) on knowledge exchange includes a section on research on the added value of eHealth tools, but this is restricted to Health Technology Assessment (HTA) work, not benchmarking ICTs. There are some benefit indicators in the EU hospital benchmarking survey (hospital statistics for the past year) (14):

- Question 46. Number of hospital discharges.

- Question 47. Average length of stay.

- Question 48. Number of emergency visits.

- Question 49. Number of outpatient consultations.

\subsection{Analysis of ongoing and recently completed eHealth projects in the EU}

In 2014, NeRN started to consider the possibilities for a joint EU Horizon 2020 application. NTNU led the process, and explored the possibilities for coordinating an application in collaboration with the National Centre for Telemedicine and presently NSE in Tromsø. NeRN had Horizon 2020 on the agenda of several meetings between 2014 and 2016. A particular focus was on the EU application in a working meeting in Aalborg (December 2014); in a workshop and information meeting with the Norwegian Research Council (represented by Trond Knudsen), Oslo Medtech (represented by Cato Bjørkli) and the Directorate for Health (represented by Irene Olaussen) in Oslo (February 2015). NeRN also had Horizon 2020 on its agenda in meetings in Helsinki (September 2015) and Tromsø (March 2016). The aim of these meetings was to learn about EU calls, to discuss how to proceed with the project, and to develop a work plan. 
The NTNU representative also had a series of meetings respectively with EU adviser Boukje Ehlen at the Faculty of Medicine at NTNU, and project support Eugen Gravningen Sørmo at the Department of neuroscience, NTNU. Gilstad (NTNU) and Andreassen (NSE) also attended EU proposal writing courses: a course at NTNU and a course organized by the Norwegian Research Council in Oslo. However, the calls that were originally considered relevant for the NeRN research focus proved not to be relevant for the eHealth indicator work. Due to limitations in the workforce at the involved department at NTNU, we had to reprioritize tasks and decided to put the application process on hold.

In 2016, NeRN resumed the work of finding a relevant call and developing an application to the EU. In order to gain deeper understanding of eHealth benchmarking in the EU-context, the NeRN network wanted to identify the eHealth projects that had been accepted for funding by $\mathrm{H}_{202 \mathrm{O}}$, and to study the characteristics of the proposals. Horizon 2020 is the current EU funding instrument for research and innovation. It entered into force in 2014 and will run until 2020. This EU Framework Programme for Research and Innovation replaced the 7th Framework Programme (FP7) 2007-2013 and CIP ICT Policy Support programme as a way of improving better coherence across different funding instruments. The final goal of Horizon 2020 is to add value to the entire innovation cycle, from research, to product development, to market deployment. Other funding sources are available through the EU Structural Funds, part of which is dedicated to investment in ICT for public services, including eHealth.

The report "eHealth projects. Research and Innovation in the field of ICT for health and well-being" (15) gave an overview of the most current (ongoing or recently finished) European funded projects in the field of ICT for health and wellbeing (eHealth). Three types of research and innovation projects were presented in the report:

- Managing your health and care projects (mental health, pain, neurological disorders, stroke, lungs, cardiovascular disorders, diabetes, cancer, pediatrics, sight and hearing, gastro, sex, rehabilitation, preventive healthcare).

- Innovating healthcare and the way we work (clinical trials and biomedical informatics, anesthesia and patient safety, knowledge sharing and infrastructure for eHealth experts and health professionals, telemedicine, patient empowerment, interoperability and cross-border healthcare, clinical research, innovation procurement, projects focused on transforming healthcare via procurement of mobile health solutions).

- International projects active in low and middle income countries.

At first glance, 19 of the projects seemed relevant to the NeRN focus. However, a closer look revealed that they focused on topics like: the design of a platform for individualized care, digital representations of patient status, infrastructure, economy, testing and certification, patient summary, drug prescription, clinical trials, semantic interoperability and monitoring of physical and mental state. None of the projects offered research on indicators for monitoring eHealth. Although a few projects also dealt directly with 
monitoring eHealth, none were overlapping with the research focus of NeRN. This vacuum offers momentum for promoting the NeRN research at the EU level.

During the mandate period, we have also analysed open EU calls to try and achieve continuation and resources for the eHealth indicator work. Those that were identified were:

- COST will fund networking activities (http://www.cost.eu/participate/open_call) and are open to researchers, engineers and scholars from universities, research centres, companies, in particular SMEs, as well as other legal entities. However, COST does not fund research, but offers a range of networking tools. The NerN group has not yet finished their discussion on whether our activities could be COST-type of "supporting actions".

- Horizon 2020 work-programme 2016-2017 (16)

Most calls in the Horizon 2016-2017 work programme are closed. Some that could have been relevant to eHealth monitoring did not fit the NeRN foci area on indicator development and benchmarking. The next work programme (2018-2020) is due to be published at the end of 2017, although we will know the calls some months in advance.

In the Tromsø meeting in March 2016, the discussion on the Horizon 2020 application concluded that in order to apply for funding, we would need to adjust our goals and expand / strengthen our relations to a) industry, and b) health sector providers. A research group focusing on monitoring activities does not qualify for existing calls Horizon 2020 work-programme 2016-2017. The only way to fit the program requirements would be to go into a project as partners, responsible for monitoring the particular applications that are of interest in the project.

In the Iceland meeting in August 2016, EU representatives from DG Sante were invited to participate on VC (Sevala Malic, DG SANTE). The aim was to exchange information on eHealth benchmarking plans (EU and NeRN), and possibilities for collaboration. The Commission representatives were informed about the work of NeRN and they were already familiar with the Norwegian work. The discussion focused on measuring the maturity of the member states' eHealth status and methodology to obtain reliable data via dedicated international surveys vs. via national surveys with common indicators, as well as possibilities of a NeRN - EU collaboration. It was stated that maturity is important for the EU, and Nordic countries are advanced compared to other member states. Regarding methodology to obtain good quality data, data offered by national bodies offer a reliable source, since the dedicated surveys are always samples, provided that there are common measures. The Nordic indicators are interesting also as a basis for Eurostat, although Eurostat has a wider focus than the Nordic focus. As a consequence, the NeRN network was invited to come and present the Nordic eHealth work to the eHN network (17). 


\subsection{Collaboration with the WHO}

The WHO work on eHealth indicators is to a large extent based on the 58th World Health Assembly in May 2005, which adopted Resolution WHA58.28 establishing an eHealth strategy for the WHO. The resolution urged Member States to plan for appropriate eHealth services in their countries. (7) The WHO's work in eHealth includes programmes and projects in areas such as policy and governance, standardization and interoperability, research and global surveys, eLearning and capacity building, networking and South-to-South collaboration, as well as eHealth applications.

In 2005, the WHO launched the Global Observatory for eHealth (GOe), an initiative dedicated to the study of eHealth - its evolution and impact on health in countries. The Observatory model combines WHO coordination regionally and at headquarters to monitor the development of eHealth worldwide, with an emphasis on individual countries. Recognizing that the field of eHealth is rapidly transforming the delivery of health services and systems around the world, the WHO is playing a central role in shaping and monitoring its future, especially in low- and middle-income countries.

The WHO has published the Global Observatory results on eHealth most recently in 2015 , based on a member state survey ( $N=125,64 \%$ of member states). One response is received from each member state. The observatory covers the following domains and country-level measures (8):

- Section 1-eHealth foundations:

- Availability of eHealth policy, funding for eHealth programmes, multilingualism in eHealth, human resources and skills (professional training, in service training).

- Section 2-mHealth:

- Availability of policies, strategies and funding; regulation; existing programmes (helpline, emergency, treatment adherence, appointment reminders, health promotion campaigns, prof. consultation, inter-sectoral communication, health monitoring and surveillance, access to info and education); programme evaluation.

- Section 3-TeleHealth:

- Availability of policies, strategies; existing programmes (radiology, dermatology, pathology, psychiatry, remote patient monitoring, other); evaluation; barriers, lessons learned.

- Section 4-elearning in health sciences:

- Pre-degree and post-degree usage, reasons, professional groups, eUniversity degrees, professionals' eCertification, programmes, evaluation.

- Section 5-Electronic Health Records:

- Availability and implementation year of a national EHR-system; legislation governing it, health facilities using it, systems that are linked to the national EHR (structured list), international standards used (structured list), barriers to 
implementing EHR-systems (structured list); other applications (billing, supply chain management, human resources system).

- Section 6-Legal frameworks for eHealth:

- Availability of legislation for medical jurisdiction, liability or reimbursement of eHealth services, patient safety and quality of care based on data quality, data transmission standards, or clinical competency criteria, privacy of personally identifiable data of individuals, sharing of digital data between health professionals; sharing of personal and health data between research entities, legislation that allows individuals electronic access to their own health-related data when held in an EHR, individuals to demand their own health-related data be corrected when held in an EHR if it is known to be inaccurate; individuals to demand the deletion of health-related data from their EHR; policies or legislation on civil registration and vital statistics; policies or legislation on national identification management systems.

- Section 7-Social media:

- Availability of policy or strategy on the use of social media by government organizations, usage purposes in healthcare organisations; citizen usage purposes.

- Section 8 - Big data:

- Availability of national policy or strategy regulating the use of big data in the health sector, policy or strategy regulating the use of big data by private companies; barriers to adopting big data for health (structured list).

- Section 9 -eHealth networks.

The domains and measures show that the WHO measures will focus mainly on the policy and programme level and availability and some usage rate measures, thus complementing, not competing with the Nordic or the OECD eHealth indicators.

The NeRN network has collaborated specifically with the eHealth Regional Focal Point for the European Region of the WHO, related to the WHO work on eHealth maturity index development. The $\mathrm{WHO}$ representatives have participated via video link in several of the NeRN meetings.

The WHO has observed a move towards standardized data collection requiring fewer resources (as our log data collection). Secondary use policies are also gaining momentum in the WHO. UK secondary use policy is a valuable reference point. Funding for monitoring is a big question. The WHO follows up closely the NeRN work, which has been promoted in the WHO report (18). Citizen's use and experiences of eHealth are very important for the $\mathrm{WHO}$, and they are willing to promote our work.

In the Iceland meeting (8-9.9.2016), the WHO representative participated via VC. It was noted that the WHO goals for harmonizing monitoring were same as in NeRN. In April this year, the WHO conducted horizon scanning on what eHealth monitoring initiatives exist (OECD, NeRN etc). The work is planned to lead to developing an eHealth maturity index. Ongoing work in EU projects, including a project that has developed a B3maturity model (readiness for integrated care) https://ec.europa.eu/research/innovation- 
union/pdf/activeHealthy-ageing/pavlickova.pdf. The WHO work is now in open consultation phase, mapping the way forward with the following procedures:

- Define draft literature, conceptualize measurements on high level and maturity.

- Digesting input - submitting paper for commenting (e.g. NeRN and EU commission).

- WHO expert meeting in 2017 after feedback -> document (e.g. WHO white paper) to be given to member states in measuring eHealth maturity.

- WHO plans: a joint document with NeRN participating.

The WHO priority is pan-European eHealth indicators, disparities from east to west. The developing of an eHealth maturity index might be a solution to this. Key players mentioned by the WHO representative are the OECD, colleagues from London, and NeRN. The WHO has asked the NeRN for comments on their maturity index work.

\subsection{Conclusions}

In summary, there is a mutual understanding of the importance of and emphasis on eHealth benchmarking within the EU, the OECD, the WHO and NeRN network that forms good ground for collaboration. The working methods of the OECD and NeRN on the one hand and the EU and WHO on the other are different, but all need harmonious, reliable data on the evolvement of eHealth maturity in the member states.

A big challenge at present is the lack of funding to develop eHealth indicators to monitor implementation of policy goals for mutual benchmarking and learning. The results of the analysis on international collaboration were condensed into the following suggestions for the purposes of NeRN work (11):

- Suggestion 1: There is a shared understanding of the importance of and emphasis on eHealth benchmarking within the EU, WHO and the OECD that forms a good basis for collaboration. The OECD, the Eurostat as well as the NeRN work is based on application of commonly agreed (model survey) variables to national data collection to ensure high quality of data, but Eurostat does not have eHealth indicators at present. The OECD, WHO and EU could benefit from mutual collaboration and collaboration with NeRN to generate policy-based, commonly agreed eHealth indicators to be reported on the EU level.

- The interest in systematic statistical reporting of eHealth benchmarking turns eHealth monitoring and benchmarking results into part of building countries' statistical knowledge-base. This needs to be recognised in the EU and country-level eHealth policies, with relevant resources reserved.

- A policy and scientific level arenas for joint Nordic and international discussion and collaboration on eHealth benchmarking should be established, in the form of e.g. EU-level joint projects, supported by a series of conference 
tracks for scientific contributions, targeted towards common EU-level eHealth indicator definition and reporting

- Suggestion 2: Secondary use of health data is high on the agenda of the OECD, EU and also Nordic eHealth policies. Interoperability, privacy concerns and trust of populations in relation to the governance of their health data as well as quality of the data stored in the health care systems are key elements to enable secondary use.

- Monitoring privacy and trust via surveys of citizens and data quality (e.g. completeness via availability and consistency via use of common classifications) seem natural continuums of the work conducted by NeRN in mandate period 3 .

- The WHO is interested in developing a maturity taxonomy of eHealth. Based on the OECD example, maturity is different for each policy goal (e.g. HIE), and one taxonomy is not enough. These taxonomies could be further developed in collaboration with the WHO. Developing indicators to monitor maturity in interoperability and Health Information Exchange seems to be in a common interest, and could be a focus for NeRN, OECD and WHO collaboration in future.

- Measuring the added value of eHealth seems to be an object of mutual interest. Testing the utility of register-based OECD Healthcare Quality Indicators as measures of the added value of eHealth for those ICT functionalities that are available, adequately used, and have relevant impact mechanisms could provide a way towards a more efficient and automated monitoring of eHealth impacts via register data.

- Suggestion 3: Citizen Empowerment is mentioned in the OECD studies, EU eHealth Action Plan as well as the Nordic eHealth policies. The OECD has developed a model survey for organisations, and NeRN has mapped common Nordic indicators from citizen surveys. Common efforts in developing a model survey for citizens could help monitor progress in eHealth-related citizen empowerment. 


\subsection{References}

(1) EU (2012) eHealth Action Plan 2012-2020 - Innovative healthcare for the 21st century. $\operatorname{COM}(2012) 736$ final. Brussels, 6.12.2012.

(2) OECD (2015b), Health Data Governance: Privacy, Monitoring and Research, OECD Health

Policy Studies, OECD Publishing, Paris. http://dx.doi.org/10.1787/9789264244566-en

(3) OECD (2015c) Health Data Governance: Privacy, Monitoring and Research - Policy Brief. www.oecd.org/health

(4) OECD (2013), Strengthening Health Information Infrastructure for Healthcare Quality Governance: Good Practices, New Opportunities and Data Privacy Protection Challenges, OECD Health Policy Studies, OECD Publishing. http://dx.doi.org/10.1787/9789264193505-en

(5) OECD (2010) Improving Health Sector Efficiency. THE ROLE OF INFORMATION AND COMMUNICATION TECHNOLOGIES. OECD Health Policy Studies, OECD Publishing, www.oecd.org/publishing/corrigenda

(6) OECD (2015a) DRAFT OECD GUIDE TO MEASURING ICTs IN THE HEALTH SECTOR. COM/DELSA/DSTI(2013)3/FINAL.

(7) WHO (2005) WHA58.28 eHealth.

(8) WHO (2015) Third Global Survey on eHealth 2015. The use of eHealth in support of universal health coverage. Global Observatory for eHealth. World Health Organization.

(9) HORIZON 2020 (2017): The EU Framework Programme for Research and Innovation, http://ec.europa.eu/programmes/horizon2020/

(10) Jennifer Zelmer, Elettra Ronchi, Hannele Hypponen, Francisco Lupia nez-Villanueva, Cristiano Codagnone, Christian Nøhr, Ursula Huebner, Anne Fazzalari, Julia Adler-Milstein. International health IT benchmarking: learning from cross-country comparisons. JAMIA, August 22, 2016.

(11) Labrique AB, Vasudevan L, Kochi E, Fabricant R, Mehl G. mHealth innovations as health system strengthening tools: 12 common applications and a visual framework. Global Health: Science and PracTlce. 2013 Aug 15;1(2):160-71.

(12) Mobile technology-based services for global health and wellness: Opportunities and challenges (2016): http://www.oecd.org/fr/sti/ieconomie/mobile-technology-based-servicesfor-global-health.htm

(13) EU eHealth Action Plan (2012-2020): https://ec.europa.eu/digital-singlemarket/en/news/ehealth-action-plan-2012-2020-innovative-healthcare-21st-century

(14) European Hospital survey (2012-2013): Benchmarking deployment of eHealth services (2012-2023).Methodological report. https://ec.europa.eu/digital-singlemarket/en/news/european-hospital-survey-benchmarking-deployment-ehealth-services2012-2013

(15) eHealth projects. Research and Innovation in the field of ICT for health and well-being: http://www.eHealthnews.eu/images/stories/pdf/research-and-innovation-in-eHealth-June2016.pdf

(16) Horizon 2020 work-programme 2016-2017: http://ec.europa.eu/research/participants/data/ref/h2020/wp/2016_2017/main/h2020-wp1617health_en.pdf

(17) NeRN work plan 2015-2017 (internal document)

(18) WHO-report (2016): http://www.euro.who.int/en/publications/abstracts/from-innovationto-implementation-eHealth-in-the-who-european-region-2016

(19) The JAseHN website: http://jasehn.eu/index.php/downloads/ 



\section{Discussion, conclusions and a way ahead}

Based on this updated policy analysis, indicators should be further developed on the following aspects of eHealth systems and services:

- The availability, update-ability, trustability and understandability of eHealth services from an end-user perspective (both clinician and citizen).

- Use and utility of the eHealth services both from end-user and health system perspectives.

- Establishing, maintenance, availability, use and utility of shared information infrastructures from the perspectives of end-users, leaders, researchers and innovators.

- Availability and utility of eHealth enabled healthcare service redesigns.

Secondary use of health data is high on the agenda of the OECD, EU and also in Nordic eHealth policies. Privacy concerns and trust of populations related to the governance of their health data are key elements to enable secondary use. Other pre-requisites for secondary use are interoperability and data quality, which also seem to be of common interest, and could be a focus for collaboration between NeRN, the OECD and the WHO in the future.

\section{Conclusion 1}

There is a shared understanding of the importance of and emphasis on eHealth benchmarking within the EU, WHO, the OECD and the Nordic countries, with very similar goals that form a good basis for collaboration. Joining forces to develop key indicators on common policy areas would serve all parties. The WHO and OECD have informed that they follow NeRN indicator work, and the EU has invited NeRN to present the policy-based NeRN methodology to generate and implement common eHealth indicators in the eHealth Network meeting in Malta in May 2017.

\subsection{Monitoring implementation of the strategies is part of most of eHealth strategies}

The eHealth group has been promoting systematic statistical reporting of Nordic eHealth maturity, which brings eHealth monitoring and benchmarking a step closer to becoming part of the Nordic countries statistical knowledge-base. However, the 
organisation and funding mechanisms for monitoring strategy implementation vary; costs are not in all cases covered. In practice, monitoring has been either project-based with related funding, arranged as a self-organised and funded activity only to a small extent, being mandated to an organisation on a permanent basis. A governance system for collection of data to monitor eHealth strategy implementation is a prerequisite for the provision of systematic, comparable monitoring data. A sustainable model for the governance of eHealth monitoring in Nordic countries needs to be developed.

At present, the lack of clear governance of eHealth monitoring work in the Nordic countries is a major obstacle preventing the provision of common indicator data to NOWBASE: To a large degree, the responsible organisations have not been selected, mandated, and resourced to take care of the task. Without a clear governance of eHealth indicator work in the Nordic countries, there is a real threat that common eHealth indicator data will remain divergent in the Nordic countries and will not be publicly available in common formats via statistical databases. This needs to be recognized in Nordic and country-level eHealth governance, with relevant resources reserved.

\section{Conclusion 2}

The interest in systematic statistical reporting of eHealth maturity turns eHealth monitoring and benchmarking results into part of building countries' statistical knowledge-base. This needs to be recognised in the EU and country-level eHealth policies, with mandating of the work and reserving of relevant resources.

Analysis of the contents of online reporting systems show that at present quite a lot of data are already available online, including reporting on the usage of eHealth services in the Nordic countries as well as potential benefits, though the content of the data vary. All the Nordic countries are using shared medication record systems. The variables for automatic monitoring of usage of the shared data and dimensions to view the data are still poorly defined and not harmonious. Common specification work with the institutions responsible for the logs is required to harmonize the reports. The utility of health care quality register data has not been explored.

\section{Conclusion 3}

Measuring the use and added value of eHealth seems to be an object of interest to the EU, OECD and WHO, as well as in NeRN. Development of common specifications for eHealth usage logs and testing the utility of common register-based Healthcare Quality Indicators as measures of added value for eHealth for those ICT functionalities that are available, are adequately used and that have relevant impact mechanisms could provide a way towards a more efficient and automated monitoring of eHealth use and impacts. 
Analysis of the citizen surveys in the different Nordic countries showed that there is clearly a potential to develop common indicators in this area. The analysis of the surveys has shown that there is a general interest in measuring the effects and preferences regarding use and re-use of eHealth to sample information, interact with health and social care, and to, in parallel, increase patient empowerment. While some countries started the collection of data some years ago, others are still in the process of developing surveys that measure the use of eHealth.

It is, however, difficult to know with the information that we have had access to how individuals have understood the surveys and if they have measured what they were intended to measure. We have had limited access to the answers sampled in the different countries.

The idea of "being digital" and using eHealth services as a tool to stimulate the empowerment of individuals with the same quality level as today is a reality for all Nordic countries. However, for different reasons, the digitalization of the eHealth area has not yet constituted a sustainable digital alternative. The degree of digitalization has combined both physical and digital resources but, from the surveys it seems that, a real digital capability has not yet been realized. Differences in the level of implementation and the use of eHealth applications are reflected in the surveys. An interesting issue is that none of the surveys asked about the IT-maturity of the end-users or for eventual constraints i.e. disabilities that could influence the possibility to access, use, and trust eHealth services. Experiences sampled from other areas have shown that this is indeed a factor that influences the use and sustainability of digital services.

After analysing and discussing the current questionnaires we will work further on the establishment of a common Nordic model survey to exploit current and to propose some additional common questions.

\section{Conclusion 4}

Citizen Empowerment is mentioned in the OECD studies, the EU eHealth Action Plan, as well as in Nordic eHealth policies. The OECD has developed a model survey for organisations, and the NeRN has mapped common Nordic indicators from citizen surveys. Common efforts in developing a model survey for citizens could help monitor progress in eHealth-related citizen empowerment as well as privacy concerns and the trust of populations related to the governance of their health data, which is a key element also for secondary use of the data.

Based on these conclusions, several tasks have been discussed within the networks as potential stepping stones towards systematic eHealth monitoring in the Nordic countries and in collaboration with the OECD, EU and WHO:

- Task 1. Developing a model survey to monitor citizens' views on eHealth.

- Task 2. Defining specifications for automated monitoring of eHealth usage and outcomes from logs and registers -, incl. mapping register-based HC quality indicators against impact mechanisms of ICT interventions 
- Task 3. Updating the availability and usage indicators with emerging new policy goals, e.g. the update-ability, trustability and understandability of eHealth services from an end-user perspective (both clinician and citizen), availability, use and utility of shared information infrastructures from the perspectives of endusers, leaders, researchers and innovators, and the availability and utility of eHealth-enabled healthcare service redesigns.

- Task 4. Monitoring eHealth competences for professionals (related to monitoring citizens digital literacy skills). What kind of professional education is available, and what is needed? Developing a module for monitoring eHealth competence via professional surveys.

- Task 5. Developing a set of indicators for monitoring secondary use of health data for $\mathrm{HC}$ quality and efficiency improvement. Secondary use depends e.g. on semantic and technical interoperability of health information systems (exploiting the OECD HIE maturity work), on data quality (incl. harmonious use of classifications) in different information systems, and on public trust.

Increased collaboration with the EU (with the eHealth Network eHN and Eurostat) to generate and report common Europe-wide eHealth-indicators is regarded by NeRN as a foremost priority. Selecting the foci and emphases for future work of the network depends on the needs and interests of Nordic policy makers and the funding bodies of the research. 


\section{Sammenfatning}

Nordisk e-helse forskernettverk (NeRN) har vært knyttet til til Nordisk Ministerråds (NCM) e-helsegruppe i perioden 2015-2017, og har hatt følgende oppgaver:

- Å foreslå en langsiktig videreføring av tidligere arbeid gjennom undersøkelser av metoder for innsamling, analyse og publisering av benchmarking- resultatene og sammenligningene mellom de nordiske landene.

- $\AA$ undersøke hvordan resultatene fra nettverkets arbeid kan brukes i en europeisk kontekst og i OECD-sammenheng.

- Å identifisere felles indikatorer som kan brukes for å analysere og sammenligne pasienters og innbyggeres bruk av, og erfaringer med, e-helsetjenester.

Metodene som ble brukt var: oppdatering av e-helsestrategianalysen fra 2012, innsamling av informasjon om rapporteringssystem og deres innhold i de nordiske landene, analyser av EU-, WHO- og OECD-dokumenter, og en sammenligning av innholdet i spørreundersøkelsene om e-helse til innbyggere i de nordiske landene.

E-helsestrategianalysen viser at det er et skifte fra et fokus på teknisk infrastruktur, til et fokus på styring og involvering av interessenter i de nordiske landene. Forretningsstøtte forblir et viktig strategisk mål. De eksisterende e-helseindikatorene utgjør et godt grunnlag for e-helsemonitorering, men det er behov for noe tilpasning. Det er spesielt to forhold som må løses for å legge til rette for langsiktig styring av ( $\mathrm{i}$ økende grad logg-basert) e-helse benchmarking-data i de nordiske landene: 1) beslutninger om styring av e-helse benchmarkings-arbeidet, og 2) samarbeid mellom flere ulike rapporteringssystem innad i hvert nordiske land, inkludert de med logg- og registerbaserte data, for å generere felles rapporter som også inkluderer logg- og registerbasert monitorering av e-helse utkomme/resultater/konsekvenser.

I de nordiske landene, EU, WHO og OECD har man en omforent forståelse av betydningen av, og vektleggingen på, e-helse benchmarking. Disse har svært like målsettinger, som er et godt grunnlag for å samarbeide om felles tiltak. De nordiske landene er ledende når det gjelder e-helseimplementering, og er også ganske avanserte når det gjelder benchmarking av e-helse. Det vil være nyttig for alle parter å gå sammen om å utvikle nøkkelindikatorer for felles strategiområder som dernest kan informere evidensbasert strategiutvikling i Norden og på EU-nivå.

Analysene av spørreskjemaene til innbyggere i de ulike nordiske landene viste at det er et stort potensiale for å utvikle felles indikatorer på dette området. Det er en generell interesse for å måle effekter og preferanser når det gjelder bruk og gjenbruk av e-helseinformasjon, samhandling mellom helse-og sosialtjenesten, og samtidig myndiggjøring av pasientene. De eksisterende spørreundersøkelsene er gode 
utgangspunkt for utvikling av en felles spørreundersøkelse for å monitorene e-helse fra innbyggeres ståsted.

Basert på resultatene har fem tiltak blitt foreslått til Nordisk Ministerråds ehelsegruppe som mulige veier å følge $i$ arbeidet mot et etablert system for benchmarking for å støtte evidensbasert e-helsestrategiutvikling i de nordiske landene. 
Nordic Council of Ministers

Ved Stranden 18

DK-1061 Copenhagen $\mathrm{K}$

www.norden.org

\section{Nordic eHealth benchmarking}

This report proposes a long-term management of earlier NeRN work to be utilized also in the European and OECD context, and indicators on patients and citizens' use and experiences of eHealth services.

An update to prior eHealth policy analysis shows an increase on governance and stakeholder involvement in all countries. The existing NeRN indicators form a good basis for continued monitoring. Common eHealth indicators from citizens' point of view are needed. Current Nordic citizen surveys offer a good basis for this. Decisions on governance of eHealth benchmarking work and of collaboration between several different reporting organisations are required for long-term maagement on eHealth benchmarking. With very similar eHealth policy goals, the EU, WHO, and OECD should join forces in defining common indicators to be collected nationally and reported internationally (e.g. by Eurostat).

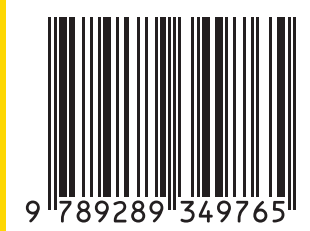

